\title{
Elevated trace elements in Posidonia oceanica and Cymodocea nodosa at six Mediterranean volcanic seeps
}

\author{
${ }^{1,2}$ Mishra, A.K., ${ }^{1}$ Santos, R., ${ }^{2,3}$ Hall -Spencer, J.M. \\ ${ }^{1}$ Centre for Marine Sciences, University of Algarve, Campus de Gambelas, Faro, 8005-139, \\ Portugal \\ ${ }^{2}$ Marine Biology and Ecology Research Centre, University of Plymouth, Plymouth, PL48A, \\ UK
}

${ }^{3}$ Shimoda Marine Research Centre, University of Tsukuba, Shizuoka, 415-0025, Japan

Corresponding author: amritkumarmishra@gmail.com

\begin{abstract}
:
Seagrasses form important habitats around shallow marine $\mathrm{CO}_{2}$ seeps, providing opportunities to assess trace element (TE) accumulation along gradients in seawater $\mathrm{pH}$. Here we assessed $\mathrm{Cd}, \mathrm{Cu}, \mathrm{Hg}, \mathrm{Ni}, \mathrm{Pb}$ and $\mathrm{Zn}$ levels in sediment and seagrasses at six $\mathrm{CO}_{2}$ seeps and reference sites off Italy and Greece. Some seep sediments had much higher concentrations of TEs, the extreme example being $\mathrm{Cd}$ at 43 -fold above reference levels. Sediment Quality Guideline (SQG) scores indicated that three seeps had sediment TEs levels likely to have "Adverse impacts" on marine biota; namely Vulcano (for $\mathrm{Hg}$ ), Ischia (for $\mathrm{Cu}$ ) and Paleochori (for $\mathrm{Cd}$ and Ni). SQG indicated seep sediments of Italian seeps were adversely affected by $\mathrm{Cu}$ and $\mathrm{Hg}$, whereas Greek $\mathrm{CO}_{2}$ seeps were affected by $\mathrm{Cd}$ and $\mathrm{Ni}$. $\mathrm{An}$ increase in sediment TEs levels positively corelated with higher levels of TEs in seagrass roots of Posidonia oceanica ( $\mathrm{Zn}$ and $\mathrm{Ni}$ ) and Cymodocea nodosa ( $\mathrm{Zn})$. Differences in the bioavailability and possible toxicity of TEs helps explain why seagrasses were abundant at some $\mathrm{CO}_{2}$ seeps but not others.
\end{abstract}

Keywords: Bioaccumulation, bioavailability, Seagrass, $\mathrm{CO}_{2}$ seeps, trace elements 


\section{Introduction:}

Around $30 \%$ of anthropogenic $\mathrm{CO}_{2}$ emissions dissolve into the surface ocean causing the $\mathrm{pH}$ to fall and altering seawater carbonate chemistry leading to ocean acidification (OA) (Caldeira and Wickett, 2003). These chemical changes are a major threat to marine species and ecosystems, the reasons why the United Nations Sustainable Development Goal 14.3 is to "Minimize and address the impacts of ocean acidification" (United Nations, 2015). Rising $\mathrm{CO}_{2}$ levels are expected to reduce marine biodiversity and alter trophic interactions (Kroeker et al., 2013; Sunday et al., 2016) which will impact a range of ecosystem services (Lemasson et al., 2017).

Metallic trace elements (both essential and non-essential) in marine ecosystem occur naturally in very low concentrations (Alloway, 1995) and are non-toxic. However, at sufficient high enough concentration elements such as $\mathrm{As}, \mathrm{Cu}, \mathrm{Pb}$ and $\mathrm{Hg}$ can be toxic and harmful to the coastal biota (Stumm Morgan, 1995). The toxicity of these elements depends on their chemical form, As for example is toxic when found in its metalloid form, $\mathrm{Hg}$ and $\mathrm{Pb}$ are toxic as free ions and $\mathrm{Cu}$ is toxic when reduced to $\mathrm{Cu}$ (I) (Tchounwou et al., 2014). A major concern is that OA will exacerbate the harmful effects of metal pollution, which is a widespread problem in coastal ecosystems (Ivanina et al., 2015; Lewis et al., 2016). OA is expected to increase the bioavailability and toxicity of metals both in sediments (Roberts et al., 2013) and the water column (Millero et at., 2009). Lower pH combined with low oxygen levels can release metals to water column that are bound to sediments (Atkinson et al., 2007) and low pH can also alter the speciation of elements like $\mathrm{Cu}$, Ni and $\mathrm{Zn}$ (Zeng et al., 2015) resulting in increased toxicity. However, the level of toxicity on marine organisms will depend on the uptake rate and interaction of metals at the receptor sites of an organism (Batley et al., 2004). Studies indicate that, the uptake and availability of elements like Cd, $\mathrm{Co}, \mathrm{Cu}, \mathrm{Hg}, \mathrm{Ni}, \mathrm{Pb}$ and $\mathrm{Zn}$ are going to increase under $\mathrm{OA}$ and low $\mathrm{pH}$ range (8.1 to 7.8) predicted for $21^{\text {st }}$ century (Byrne et al., 1998; Richards et al., 2011). For example, seawater free ion concentration of $\mathrm{Cu}$ is expected to increase by $115 \%$ (Pascal et al., 2010; Richards et al., 2011), Pb by 4.56\% (Millero et al., 2009; Dong et al., 2016) whereas Cd concentration may decrease or be unaffected (Pascal et al., 2010) under OA and low pH scenarios. But the increase in free ions is predicted to increase the toxicity of metals under OA (LacoueLabarthe et al., 2009; 2012). 
Most studies on the bioavailability of trace metals at elevated $\mathrm{CO}_{2}$ have been carried out in laboratory conditions (Besar et al., 2008; Richir \& Gobert, 2013; Bravo et al., 2016) which undermines the complex behaviour of trace elements in marine environment. The ecological risk posed by the effects of $\mathrm{OA}$ on metal contaminated water column and sediments is difficult to assess in the laboratory (Millero et al., 2009), which emphasizes the importance of studies on the interplay between trace elements and OA in-situ. Submarine hydrothermal activity is of interest as this causes natural gradients in both ocean acidity and trace elements, providing natural conditions to assess their combined effects (Monia Renzi et al., 2011; Kadar et al., 2012; Vizzini et al., 2013) on marine biota. While relationships among organisms, environmental factors and trace elements have received much attentions at deep sea hydrothermal vents (Kadar et al., 2007; Cravo et al., 2007), those of shallow marine $\mathrm{CO}_{2}$ seeps are still little understood.

Shallow water $\mathrm{CO}_{2}$ seeps represent natural analogues for future coastal ecosystems, providing entire seabed of marine communities exposed to the shifts in carbonate chemistry (low pH) expected for $21^{\text {st }}$ century (Hall-Spencer et al., 2008; Enochs et al., 2015; Connell et al., 2017). At such seeps, there are often elevated levels of trace elements and hydrogen sulphide $\left(\mathrm{H}_{2} \mathrm{~S}\right)$ (Kadar et al., 2012; Boatta et al., 2013; Vizzini et al., 2013) combined with low pH that may be harmful to marine biota (Barry et al., 2010; Lauritano et al., 2015; Olivé et al., 2017). At these $\mathrm{CO}_{2}$ seeps, habitat forming marine fauna (such as macroalgae and seagrass) are observed (Apostolaki et al., 2014; Vizzini et al., 2010) which provides a window of opportunity to investigate the combined effects of OA and metal levels on seagrass. However, the seagrass population are not evenly abundant around these $\mathrm{CO}_{2}$ seeps, for example lush stands of seagrass are observed at some seeps off Ischia in the Mediterranean Sea and at several sites around Papua New Guinea (Hall-Spencer et al., 2008; Russel et al., 2013), whereas seagrass abundance is less at $\mathrm{CO}_{2}$ seeps off Panarea and Vulcano off Italy, where $\mathrm{H}_{2} \mathrm{~S}$ and elevated trace elements appear to affect the plants (Vizzini et al., 2010, 2013). Saying that, studies on seagrass eco-physiology at these $\mathrm{CO}_{2}$ seeps have provided mixed results, for example, Posidonia oceanica antioxidant stress related genes are more expressed near volcanic seeps (at Panarea and Ischia Islands, Italy), whereas the expression of genes involved in photosynthesis and growth responses of Cymodocea nodosa near a seep off Vulcano islands, Italy were contrary to the expected beneficial effects of $\mathrm{CO}_{2}$ (Olivé et al., 2017). On the other hand, under experimental $\mathrm{CO}_{2}$ enrichment there was a 
significant increased expression of $C$. nodosa transcripts associated with photosynthesis, as expected (Ruocco et al., 2017).

Seagrass are important coastal habitats due to their high productivity and biodiversity (Thom, 2001). They provide food nurseries for fish, turtles and mammals (Coles et al., 2007), they can be major carbon sinks and can sequester contaminants such as excess nutrients and metals (Orth et al., 2006; Fourqurean et al., 2012). Seagrass productivity is predicted to increase as $\mathrm{CO}_{2}$ levels continue to rise if temperature increases do not become too stressful (Koch et al., 2013; Brodie et al., 2014). Seagrasses accumulate trace elements and so are used as bioindicator in coastal ecosystems (Catsiki and Panayotidis, 1993). The plants take in trace elements via the roots, rhizomes or the leaves and can translocate them between these tissue compartments (Ralph et al., 2006). The rate of uptake varies between essential and non-essential trace elements and between tissues and this introduces these substances into the food web via grazing and decomposition (Lewis and Devereux, 2009). For instance, Cymodocea serrulata transfers trace elements to detrital feeders (Klumpp et al., 1989).

Laboratory studies have shown that, at elevated $\mathrm{CO}_{2}$ and above threshold levels $\mathrm{Cu}$, $\mathrm{Pb}$ and $\mathrm{Zn}$ exert toxic effects on the physiology of the seagrasses Zostera capricorni (AmboRappe et al., 2007) and Halophila ovalis (Ambo-Rappe et al., 2011). Many $\mathrm{CO}_{2}$ seeps around Greece and Italy have seagrass (Hall-Spencer et al., 2008; Vizzini et al., 2010; Apostolaki et al., 2014). Little is known about the trace metal content, their accumulation in seagrass roots, rhizomes and leaves at $\mathrm{CO}_{2}$ seeps..

Here we expand on the work undertaken by Vizzini et al., (2013) to quantify the concentrations of trace elements, in sediments and seagrass at multiple seep sites around the Mediterranean. Our aim was to find out whether increased levels of trace elements near seeps correlate with increases in trace elements accumulation in seagrass roots, rhizomes and leaves and whether seagrass have preferences in metal accumulation patterns.

\section{Methods:}

Study sites

We surveyed six sites in the Mediterranean Sea, all of which had seagrasses (Posidonia oceanica or Cymodocea nodosa) growing on sandy bottom in high salinity and high alkalinity (Table 1). At each site, a high $\mathrm{CO}_{2}$ station and a reference station were 
sampled between May - July 2014. The annual temperature range was around $18-22^{\circ} \mathrm{C}$ for all six locations and the $\mathrm{CO}_{2}$ seeps were at 0-10 m depth with a tidal range of 0.30-0.50 m.

Vulcano, Italy

We sampled Levante Bay (38.4 N, 15.0 E) off Vulcano island (Fig. 1A). The underwater gas emissions are $97-98 \% \mathrm{CO}_{2}$ with $2.2 \%$ hydrogen sulfide $\left(\mathrm{H}_{2} \mathrm{~S}\right)$ close to the seeps, decreasing to less than $0.005 \% \mathrm{H}_{2} \mathrm{~S}$ towards the north-eastern part of the bay (Capaccioni et al., 2001; Milazzo et al., 2014). Cymodocea nodosa was absent near the main vents so we, collected it on the periphery of the $\mathrm{CO}_{2}$ seeps at $1 \mathrm{~m}$ depth.

Ischia, Italy

At the Castello Aragonese, off Ischia (404' $50.4^{\prime \prime N}$; $\left.13^{\circ} 57^{\prime} 48.2^{\prime \prime} \mathrm{E}\right) \mathrm{CO}_{2}$ bubbles up in shallow water seeps (Fig. 1A). Here the gas is $90-95 \% \mathrm{CO}_{2}, 3-6 \% \mathrm{~N}_{2}, 0.6-0.8 \% \mathrm{O}_{2}, 0.2-$ $0.8 \% \mathrm{CH}_{4}$ and $0.08-0.1 \%$ air and the seeps lack $\mathrm{H}_{2} \mathrm{~S}$ (Tedesco, 1996). Here Posidonia oceanica meadows were sampled at $0.5 \mathrm{~m}$ depth from the seep area and from a northward reference site with no $\mathrm{CO}_{2}$ bubbling (Fig.2a).

\section{Panarea, Italy}

Panarea island $\left(38^{\circ} 38^{\prime} 12.2^{\prime \prime} \mathrm{N} ; 5^{\circ} 06^{\prime} 42.5^{\prime \prime} \mathrm{E}\right)$ is part of the Aeolian Archipelago in the Southern Tyrrhenian Sea (Fig.1A). On the main island and on the surrounding seafloor, tectonic faults have many gas seeps (Gabianelli et al., 1990; Voltattorni et al., 2009). The underwater gas emissions around these seeps are $92-95 \% \mathrm{CO}_{2}, 2.99-6.23 \% \mathrm{~N}_{2}, 0.69-1.2 \% \mathrm{O}_{2}$ and $0.65-3 \% \mathrm{H}_{2} \mathrm{~S}$ (Caramanna et al., 2010). Here P. oceanica was sampled at $5 \mathrm{~m}$ depth.

\section{Milos Islands, Greece}

Adamas thermal springs (36.70 N, 24.46 E) and Paleochori Bay (36.67 N, 24.51 E) are situated on southwest and southeast part of Milos island respectively (Fig.1B). Milos island is part of an extensive submarine venting, from the intertidal to depths of more than $100 \mathrm{~m}$ (Dando et al.,1999). The underwater gas seeps at Adamas and Paleochori are located $<1$ to $4 \mathrm{~m}$ depth. The released gases are mainly composed of $92.5 \% \mathrm{CO}_{2}$ with some $\mathrm{CH}_{4}$ and $\mathrm{H}_{2}$ (Bayraktarov et al., 2013). Cymodocea nodosa meadows were sampled at $4 \mathrm{~m}$ depth at Paleochori Bay and 2m at Adamas thermal station (Fig.2b).

\section{Methana, Greece}


The Methana peninsula (37.638428 N; 23.359730 E) is the westernmost volcanic system of the northern Aegean Volcanic Arc (Fig.1B), derived from the subduction of the African tectonic plate beneath the Eurasian plate. We sampled the area described by Baggini et al., (2014) near Agios Nikolaos village on the NE part of the peninsula. The gases were $90 \% \mathrm{CO}_{2}$, with small amounts of nitrogen, carbon monoxide and methane (D'Alessandro et al., 2008). Here we sampled Posidonia oceanica meadows at 8-10 m depth.

\section{Water sampling}

Water samples $(n=5)$ were collected at each $\mathrm{CO}_{2}$ seep and Reference station of all six sites in $100 \mathrm{ml}$ Winkler bottles and were fixed with $20 \mu 1$ mercuric chloride in the field, stored in dark cool- boxes and transported to the laboratory for total alkalinity (TA) analysis. The $\mathrm{pH}_{\mathrm{NBS}}$ (using $\mathrm{pH}$ meter, Titrino Methron, Thermo Scientific) and temperature of the water samples were measured in the field immediately after collection. In the laboratory 80 $\mathrm{ml}$ water samples were analysed for TA using a Lab Titrino analyser following methods given by Dickson et al., (2007). Sterilized sea water was used as reference materials (CRM Batch 129, accuracy-98.7\% Dickson, 2013) for TA analysis. Hanna buffer (HI7007L, Hanna Instruments, accuracy-99\%) was used to calibrate the $\mathrm{pH}$ electrodes. Temperature, $\mathrm{pH}_{\mathrm{NBS}}$ and TA data were used to calculate $p \mathrm{CO}_{2}$ using $\mathrm{CO}_{2} \mathrm{SyS}$ program following methods given by Pierrot et al., (2006). Dissociation constants $\left(\mathrm{K}_{1}\right.$ and $\left.\mathrm{K}_{2}\right)$ developed by Meherbach et al., (1973) and refitted by Dickson et al., (1987) and dissociated constant for boric acid $\left(\mathrm{K}_{\mathrm{B}}\right)$ developed by Dickson et al., (2007) was used in $p \mathrm{CO}_{2}$ calculation.

\section{Sediment \& seagrass sampling}

Sediment samples $(\mathrm{n}=5)$ mostly sand was collected from $\mathrm{CO}_{2}$ seep and Reference stations of all six sites by SCUBA diving. A $10-\mathrm{cm}$ long and $2 \mathrm{~cm}$ diameter syringe with the tip cut off to was used to suck up the upper $5 \mathrm{~cm}$ of sand. From each station $\left(\mathrm{CO}_{2}\right.$ seep and Reference) five points were selected randomly (1m apart) to collect samples. The sediment samples were stored in plastic bags in dark boxes and transferred to lab. In the laboratory they were dried at $40^{\circ} \mathrm{C}$ in an oven till a constant weight was achieved and then analysed for the grain size following dry sieving at Half Phi intervals (Blott and Pye, 2001). After grain size analysis the fine and very fine of sediment fraction $(<180-63 \mu \mathrm{m})$ were collected and stored in plastic bottles for trace metal analysis. 
Samples ( $\mathrm{n}=5$, whole plants) of Cymodocea nodosa (from Vulcano, Adamas and Paleochori islands) and Posidonia oceanica (from Ischia, Panarea and Methana) were collected by SCUBA diving up to 10-m depth at the $\mathrm{CO}_{2}$ seep and Reference stations of all six sites. The seagrasses were rinsed well to remove sediments, razor scraped to remove leaf epiphytes, leaf scales removed from rhizomes ( $P$. oceanica) by hand and with soft toothbrush and then washed with distilled water, air-dried and stored in polybags until analyses. Seagrass leaves, roots and rhizomes were oven dried at $40^{\circ} \mathrm{C}$ and powdered in a mortar and stored till further analysis.

\section{Analytical Methods}

Total trace elements $(\mathrm{Cd}, \mathrm{Cu}, \mathrm{Hg}, \mathrm{Ni}, \mathrm{Pb}$ and $\mathrm{Zn})$ concentration was determined using Aqua Regia Soluble Total method (Modified by Laboratory of the Government Chemist (LGC) UK from ISO11466). Dried sediment (0.25 g) was put into digestion tubes (Tecator type). Cold and concentrated acids in the order: $4.5 \mathrm{~mL}$ Hydrochloric acid $(\mathrm{HCl}$,): $1.5 \mathrm{~mL}$ Nitric acid $\left(\mathrm{HNO}_{3}\right)$ was added to the tubes. The digestion tubes were left to pre-digest, for one hour then heated for 2 hours at $95-100^{\circ} \mathrm{C}$. After cooling, the digest was filtered quantitatively into a volumetric flask and diluted using $2 \% \mathrm{HNO}_{3}(25 \mathrm{ml}$ volume).

For dried seagrass (leaves, rhizomes and roots), $0.25 \mathrm{~g}$ of sample was added to $6 \mathrm{~mL}$ of $\mathrm{HNO}_{3}$ following the same procedure as metals and the volume was made up to $25 \mathrm{~mL}$. Similarly, blanks and standards (LGC Reference Materials, UK, recovery-95\%) used for sediments (LCG6156) and plants (LGC7162) were prepared using the same method. Analysis of $\mathrm{Cd}, \mathrm{Co}, \mathrm{Cu}, \mathrm{Hg}, \mathrm{Pb}$ and $\mathrm{Zn}$ was performed using an ICP-MS (Thermo Scientific, iCAP 7000 Series) and an ICP-AES (Thermo Scientific, X Series-2) in triplicate with analytical detection precision of $99.5 \%$.

All acids were analytical grade. Normal precautions for metal analysis were observed throughout the analytical procedures. $\mathrm{HCL}(37 \% \mathrm{w} / \mathrm{w})$ and $\mathrm{HNO}_{3}(69 \% \mathrm{w} / \mathrm{w})$ were Ultrapure type (Ultrapure, Fischer Chemicals, USA). All glassware was soaked overnight in 10\% $\mathrm{HNO}_{3}$ and washed with distilled water and oven dried before use.

\section{Data Analysis}

To assess the sediment quality of all six locations we used Sediment Quality Guidelines Quotient (SQG-Q, Long and MacDonald, 1998). Among the environmental quality indices in the literature, this was chosen for its simplicity, comparability and 
robustness as reported by Caeiro et al., (2005). The SQG-Q consists of two values: a threshold effects level (TEL) and a probable effect level (PEL) (MacDonald et al., 1996). TEL and PEL, represent concentrations below which adverse biological effects occur rarely and frequently.

The SQG-Q was calculated as follows:

$$
\text { SQG-Q }=\left(\square^{\mathrm{n}}{ }_{\mathrm{i}=1} \text { PEL-Qii }\right) / \mathrm{n}
$$

Where PEL-Q $\mathrm{i}_{\mathrm{i}}=$ contaminant/PEL. The PEL-Qi represents the probable effect level quotient (PEL-Q) of the $\mathrm{i}$ contaminant and $\mathrm{n}$ represents the total number of contaminants (trace metals). Using the SQG-Q index, the sediments were divided into three categories as established by MacDonald et al. (2000). SGQ-Q $\leq 0.1$ - low potential for adverse biological effects; $0.1<$ SQG-Q $<1$ - moderate potential for adverse biological effects; SQG-Q $\geq 1$ - high potential for adverse biological effects.

To assess bio-accumulation of elements, we calculated the Bio Sediment Accumulation Factor (BSAF), which is defined as the ratio between metal concentration in the organism and that in the sediment (Lau et al., 1998; Szefer et al., 1999), given by:

$$
\mathrm{BSAF}=\mathrm{Mp} / \mathrm{Ms}
$$

Where $\mathrm{Mp}$ is the concentration of the element in the seagrass and Ms is the concentration of the element in the sediment (Fergusson. 1990). BSAF is a key factor in expressing the efficiency of seagrass species to absorb elements from sediments and concentrate specific element in its roots, rhizomes or leaves. Higher BSAF values $(>1)$ indicate a greater capability of accumulation (EPA, 2007).

\section{Statistics}

A three-way ANOVA was used to test for significant differences in trace element concentration among plant compartments (leaves, rhizomes, roots), sediments and stations (Reference, $\mathrm{CO}_{2}$ seeps) in each Posidonia oceanica sites (Ischia, Panarea and Methana) and each Cymodocea nodosa sites (Adamas, Paleochori and Vulcano). All data was pre-checked for normality and homogeneity of variances. When variances were not homogenous, data were $\ln (x+1)$ transformed. In some cases, ANOVA main effect was difficult to interpret due to the presence of statistically significant interactions, then Holm-Sidak test was performed for a posteriori comparison among levels to check significant main effects in ANOVA. Pearson's correlation co-efficient was applied to identify correlations between trace element 
concentration in sediment and seagrass compartments, after testing for normality of distribution on raw or log transformed data. When normality was not achieved, nonparametric Spearman's rank correlation coefficient was applied. All statistical tests were conducted with a significance level of $\alpha=0.05$ and data were reported as mean \pm standard error (SE). 


\section{Results}

Dissolved $\mathrm{CO}_{2}$ concentrations were highest (and $\mathrm{pH}$ lowest) at each of the seeps; reference sites had normal $\mathrm{CO}_{2}$ and $\mathrm{pH}$ levels. Among all six $\mathrm{CO}_{2}$ seep sites, Panarea was observed with lowest $\mathrm{pH}(7.47 \pm 0.04)$ level, whereas Vulcano $\mathrm{CO}_{2}$ seeps were observed with highest $\mathrm{pH}(7.98 \pm 0.08)$. The salinity, temperature and total alkalinity were not affected by the seeps (Table 1).

Trace element levels were generally significantly higher in the sediments of seeps than at reference sites (Figs. 3and 4). The highest differences were found for $\mathrm{Ni}$ at Panarea (5.3-fold), $\mathrm{Cd}$ at Paleochori (42.6-fold) and $\mathrm{Cu}$ at Adamas (8.9- fold) seep sediments than reference sites. Mercury was only observed at $\mathrm{CO}_{2}$ seeps off Italy, with the highest level observed within sediment of Vulcano $(0.83 \pm 0.15 \mathrm{mg} / \mathrm{Kg})$. Zinc sediment concentrations were similar at all locations but were lowest at Methana $(15.67 \pm 1.5 \mathrm{mg} / \mathrm{Kg})$. However, $\mathrm{Zn}$ levels at the seeps of Panarea were 2.3-fold higher than reference sites.

Grain size analysis showed that $99 \%$ of the sediment particles sampled at all locations were sand(Annex-1). The quality of the seep sediments derived from SQG-Q was usually in the moderate to adverse range than the quality of reference sites at all locations (Table 2). Saying that, the probable ecological risk of trace element levels at $\mathrm{CO}_{2}$ seeps were higher with elements such as $\mathrm{Hg}$ at Vulcano, $\mathrm{Cu}$ at Ischia plus $\mathrm{Ni}$ and $\mathrm{Cd}$ at Paleochori to have adverse biological effects on seagrass sediment associated biota. (Table 2).

We were especially interested in results from Ischia as it had an abundant $P$. oceanica meadow within the main $\mathrm{CO}_{2}$ seep area and has been generally considered a low toxic environment. This seep has the highest $\mathrm{Cu}(114.60 \pm 0.64 \mathrm{mg} / \mathrm{Kg})$ and $\mathrm{Pb}(14.25 \pm 0.29$ $\mathrm{mg} / \mathrm{Kg}$ ) concentrations of all the seep locations we sampled, but seagrass tissue analyses showed low levels of these metals (Figs. 3 and 4). On the other hand, the plant compartments of $P$. oceanica at the seeps of Ischia showed higher concentrations of $\mathrm{Hg}(0.72 \pm 0.01 \mathrm{mg} / \mathrm{Kg})$, $\mathrm{Ni}(5.78 \pm 0.16 \mathrm{mg} / \mathrm{Kg}), \mathrm{Cd}(4.75 \pm 0.60 \mathrm{mg} / \mathrm{Kg})$ and $\mathrm{Zn}(115.44 \pm 1.80 \mathrm{mg} / \mathrm{Kg})$ than the sediment (Fig.3). Interestingly, at the Paleochori seep, Ni $(43.27 \pm 2.25 \mathrm{mg} / \mathrm{Kg}$ ) and $\mathrm{Cd}$ $(7.76 \pm 0.30 \mathrm{mg} / \mathrm{Kg})$ concentrations were very high in the sediments but not within $C$. nodosa plant compartments(Fig.4). Mercury and $\mathrm{Zn}$ were also found in high concentrations in the leaves of both P. oceanica and C. nodosa (Figs. 3 and 4).

Trace element levels were generally significantly higher in the roots than rhizomes and leaves of $P$. oceanica and C. nodosa at all seep locations. (Figs.3 and 4) indicating uptake 
from sediment and storage within plant compartments. Exceptions were the highest $\mathrm{Cd}$ $(4.75 \pm 0.20 \mathrm{mg} / \mathrm{Kg})$ concentrations within the rhizomes and $\mathrm{Cu}(58.38 \pm 1.01 \mathrm{mg} / \mathrm{Kg})$ within leaves of $P$. oceanica which were not observed in C. nodosa. Mercury and $\mathrm{Zn}$ were also observed in high concentrations in the leaves of both $P$. oceanica $(0.41 \pm 0.09 ; 390.33 \pm 13.48$ $\mathrm{mg} / \mathrm{Kg}$ ) and C. nodosa $(0.54 \pm 0.10 ; 30.93 \pm 2.15 \mathrm{mg} / \mathrm{Kg})$ (Figs.3 and 4).

Significant difference in levels of trace elements in sediment and seagrass compartments were observed for $P$. oceanica between three sites (Table 3). Element concentrations measured in sediments and $P$. oceanica compartments differed significantly except for $\mathrm{Cu}$ (sediment-leaves) and $\mathrm{Zn}$ (sediment-roots), whereas within P. oceanica compartments all elements except $\mathrm{Pb}$ (roots-leaves) showed significant difference at all three sites.

Significant variation was observed in trace elements level for $C$. nodosa between the three sites except for $\mathrm{Cu}$ at Adamas vs Paleochori and Ni at Vulcano vs Adamas (Table 4). Element levels measured in sediment and in C. nodosa compartments differed significantly except for $\mathrm{Cu}$ (sediment vs rhizomes), whereas within plant compartments significant difference was not observed for $\mathrm{Zn}$ (rhizomes vs leaves) and Cd (rhizomes vs leaves) at all three sites.

The Bio Sediment Accumulation Factor index indicated that both $C$. nodosa and $P$. oceanica roots and leaves accumulated trace elements from sediment. In $P$. oceanica $\mathrm{Cd}, \mathrm{Cu}$, $\mathrm{Hg}, \mathrm{Ni}, \mathrm{Pb}$ and $\mathrm{Zn}$ were observed with $\mathrm{BSAF}>1$ in the roots or leaves at all three $\mathrm{CO}_{2}$ seeps. Trace elements $\mathrm{Cd}, \mathrm{Cu}, \mathrm{Ni}$ and $\mathrm{Zn}$ were observed with $\mathrm{BSAF}>1$ in the roots and leaves of $C$. nodosa at all three $\mathrm{CO}_{2}$ seeps. BSAF>1 for elements in both seagrass roots and leaves indicate these parts of the plant accumulated higher level of elements at $\mathrm{CO}_{2}$ seeps.

Correlations between trace element content in sediments and those recorded in $P$. oceanica compartments were significant and positive for $\mathrm{Zn}$ and $\mathrm{Ni}$ in rhizomes at Ischia and Panarea seeps respectively (Table 5). Correlations were negative for $\mathrm{Ni}$ and $\mathrm{Cd}$ in rhizomes at Methana and Panarea seeps respectively (Table 5). The correlation for element content between any two organs of $P$. oceanica were positive and significant for $\mathrm{Cd}$ and negative for $\mathrm{Cu}$ at Ischia $\mathrm{CO}_{2}$ seeps (Table 5).

Correlations of trace element content in sediment and those found in rhizomes of $C$. nodosa at Vulcano were significant and positive, whereas significant and negative correlation were observed for $\mathrm{Zn}$ content between sediment and rhizomes and leaves (Table 6). For any 
two plant organs Cd was found with positive co-relation at Vulcano, where significant and negative correlation was observed for $\mathrm{Cu}$ and $\mathrm{Hg}$ at Vulcano and $\mathrm{Cu}$ at Adamas (Table 6).

\section{Discussion}

Shallow water $\mathrm{CO}_{2}$ seeps have been used as natural analogues for future coastal ecosystems as they can have areas of seabed where entire communities of marine organisms are exposed to the shifts in carbonate chemistry that are expected due to continued anthropogenic $\mathrm{CO}_{2}$ emissions (Hall-Spencer et al., 2008; Enochs et al., 2015; Connell et al., 2017). At such seeps, there are often elevated levels of $\mathrm{H}_{2} \mathrm{~S}$ and trace elements (Vizzini et al., 2010; Kadar et al., 2012; Boatta et al., 2013) so care is needed when using them to assess the effects of low $\mathrm{pH}$ due to confounding factors that may be harmful to marine biota (Bary et al., 2010). The six $\mathrm{CO}_{2}$ seeps that we survey had gradients in seawater $\mathrm{pH}$ conditions with sediments that were enriched with $\mathrm{Cd}, \mathrm{Cu}, \mathrm{Hg}, \mathrm{Ni}, \mathrm{Pb}$ and $\mathrm{Zn}$. This was expected since hydrothermal seeps sediments often have high levels of metals (Aiuppa et al., 2000; Sternbeck et al., 2001) due to continuous input from the subsea floor into the sediments (Dando et al., 2000; Hall-Spencer et al., 2008). Our calculated Sediment Quality Guidelines Quotient (Long et al., 1998; MacDonald et al., 2000) suggests Hg (at Vulcano), Cu (at Ischia) plus Cd and Ni (at Paleochori) were at high enough levels to possibly have adverse impacts on seagrass associated biota.

The mean trace element range measured within the $\mathrm{CO}_{2}$ seep sediments in our research were lower compared to mean element levels observed around Mediterranean coast of Italy and Greek (Table 7), except for $\mathrm{Cu}$ (12.10-114.60) at Italy and Ni (6.91-44.37) at Greek sites (Figs 3 and 4). However, trace element levels observed at the sediments of $\mathrm{CO}_{2}$ seeps of Vulcano, Italy were in the same range measured by Vizzini et al. (2013), whereas for sediments of Panarea $\mathrm{CO}_{2}$ seeps, Pb concentration in our results (Fig. 3) were 5-fold lower from the findings of Monia Renzi et al. (2011).Lower levels of trace elements in the sediments can be due to lower level of input from $\mathrm{CO}_{2}$ seeps compared to the anthropogenic input the Mediterranean coast receives and the sediment redox potential values which determines the binding and deposition of elements in the sediments (Monia Renzi et al. 2011). Secondly, the binding of trace elements in the sediments depends on the clay particles $(<63 \mu \mathrm{m})$, which were significantly lower in our studies as majority of the sediments were sand at $\mathrm{CO}_{2}$ seeps. 
Element levels were higher in seagrass compartments at the seep sites compared to reference sites. Mean range of elements measured in Posidonia oceanica leaves, rhizomes and roots at $\mathrm{CO}_{2}$ seeps were higher, lower or equivalent to mean range of elements observed around Mediterranean coast of Greek and Italy (Table 7). Elements such as $\mathrm{Cu}$ (2.4-fold) and $\mathrm{Hg}$ (4-fold) in leaves, $\mathrm{Cd}$ (1.6-fold) and $\mathrm{Hg}$ (1.4-fold) in rhizomes and $\mathrm{Cu}$ (2.1-fold) and $\mathrm{Hg}$ (1.6-fold) in roots at $\mathrm{CO}_{2}$ seeps of Ischia and Panarea were higher than the levels observed for $P$. oceanica off Italy coast (Table 7). However, the element levels at the $\mathrm{CO}_{2}$ seeps of Methana for $P$. oceanica compartments were lower than the element levels observed off Greek coast, except for $\mathrm{Ni}$ in rhizomes (Table 7). C. nodosa element levels at $\mathrm{CO}_{2}$ seeps of Milos Islands were lower compared to element levels of Greek coast (Table 7) except for Ni (4-fold) in rhizomes and $\mathrm{Cd}(1.5$-fold) and $\mathrm{Cu}$ (2-fold) in roots, which were higher. However, at the seeps of Vulcano elements such as $\mathrm{Cd}$ (2-fold), $\mathrm{Cu}$ (9.8-fold), $\mathrm{Hg}$ (2-fold), $\mathrm{Ni}$ (4.8-fold) and $\mathrm{Zn}$ (1.6-fold) in roots, $\mathrm{Cu}$ (1.1-fold) and $\mathrm{Hg}$ (1.3-fold) in rhizomes and $\mathrm{Ni}$ (1.6-fold) in leaves were higher than element levels observed for Italy coast (Table 7). This suggests that, there is multi-fold variation in element input and accumulation from the sediments at the $\mathrm{CO}_{2}$ seeps at different sites and species, which has been observed for P. oceanica and C. nodosa around the Mediterranean coast (Bonanno and Bonaca,2017). This also agrees with the fact that seagrass element accumulation is more element and seagrass tissue-specific rather than species-specific (Bonanno and Bonaca, 2017) resulting in seagrass compartments acting as metal accumulators of their surrounding environment, especially of heavy metals (Govers et al., 2014).

Majority of accumulation of elements in both seagrasses at $\mathrm{CO}_{2}$ seeps were observed in roots >rhizomes $>$ leaves, which is common for $P$. oceanica and $C$. nodosa (Bonanno and Bonaca,2017). Root accumulation is common in both terrestrial and aquatic plants where they store certain elements to avoid damage to photosynthetic apparatus. However, significant population declines due to higher element levels in root biomass have not been reported (Lafabrie et al., 2007). Saying that, the storage and translocation of elements such as $\mathrm{Cd}, \mathrm{Ni}$ and $\mathrm{Pb}$ as observed at $\mathrm{CO}_{2}$ seeps within seagrass compartments from roots-rhizomes- leaves, suggests seagrass may adopt a strategy depending on their physiology to either accumulate elements in the below ground root biomass or move out the elements through the leaves which are then shed, as observed in P. oceanica (Di Leo et al., 2013; Richir and Gobert, 2016) and in C. nodosa (Malea and Haritinoids, 1999; Bonanno and Di Martino, 2016). Other findings have also reported that seagrasses prefer to accumulate certain elements such as $\mathrm{Cd}$ 
and Ni that are essential micronutrients (Sanz-Lazaro et al., 2012) rather than $\mathrm{Hg}$ or $\mathrm{Pb}$ that are toxic (Kabata-Pendias and Mukherjee, 2007), which has been observed for accumulation of $\mathrm{Zn}$ over $\mathrm{Pb}$ in both $P$. oceanica (Sanchiz et al., 2001) and $C$. nodosa (Malea and Haritonidis, 1999; Llagostera et al., 2011).

Correlation results between elements in sediment and that in seagrass compartments indicated that the preferable accumulation pattern of elements from sediments are not always the sediment-root pathways, even though higher element concentrations were observed in the sediments at $\mathrm{CO}_{2}$ seeps. For instance, in $P$. oceanica $\mathrm{Cd}$, was found with a negative correlation through sediment-root and $\mathrm{Cu}, \mathrm{Ni}$ and $\mathrm{Zn}$ through root-rhizome-leaves pathway, whereas in $C$. nodosa negative correlation was found for $\mathrm{Zn}$ between sediment-rhizomes and leaves. Negative correlation suggests that the preferable route for $\mathrm{Cd}, \mathrm{Cu}, \mathrm{Ni}$ and $\mathrm{Zn}$ transfer and translocation in P. oceanica (Lafabrie et al., 2007; Di Leo et al., 2013) and $\mathrm{Zn}$ in $C$. nodosa (Malea et al., 1999) compartments is through water column at $\mathrm{CO}_{2}$ seeps rather than the sediment-root pathways. Similarly, elements such as $\mathrm{Hg}$ with negative correlation in $C$. nodosa, suggests $\mathrm{Hg}$ being toxic is not allowed for translocation within the seagrass compartments (Sanchiz et al., 2001). Similar results of transfer and translocation of elements (both essential and toxic) within seagrass compartments were observed for P. oceanica, $C$. nodosa and Halophila stipulacea of Mediterranean Sea, where the seagrass species have shown high element mobility from water column and highly variable element and speciesspecific translocation capabilities (Malea and Kevrekidis, 2013; Bonanno et al., 2017; Bonanno and Raccuia, 2018).

Correlation data between both seagrass compartments are different because element accumulation patterns in seagrass are governed by multitudes of factors (Llagostera et al., 2011). Higher element concentrations in seagrass roots, rhizomes and leaves in our studies at $\mathrm{CO}_{2}$ seeps indicate the capacity of seagrass to absorb element simultaneously from sediments and water, as they are always submerged. Absorbing elements simultaneously at these $\mathrm{CO}_{2}$ seeps have helped the seagrasses to adapt and manage stressful element levels found in sediments and regulate their gene expression to increased metal stress which have been observed for $P$. oceanica by Lauritano et al., (2015) and for $C$. nodosa by Olive et al., (2017).

At $\mathrm{CO}_{2}$ seeps the low $\mathrm{pH}$ can alter the metal speciation and favour the release of metals from sediment (Simpson et al., 2004: Atkinson et al., 2007). The chemical form in which metals are present (e.g. whether they are bound to organic or inorganic compounds) is 
a key issue determining its bioavailability. Low $\mathrm{pH}$ of seawater near the $\mathrm{CO}_{2}$ seeps tends to release the metals that are less strongly associated with sediments, increasing their potential bioavailability (Riba et al., 2004). Thus, low pH can increase the concentration of certain dissolved metals, which could affect the sediment-seagrass associated biota e.g., by increasing $\mathrm{Cu}, \mathrm{Cd}$ and $\mathrm{Zn}$ bio-availability, their accumulation and possible toxic effects (Basallote et al., 2014).

In our research, all the $\mathrm{CO}_{2}$ seeps had low $\mathrm{pH}$ (7.4-7.9) conditions, which are known to increase the availability of $\mathrm{Cd}, \mathrm{Cu}, \mathrm{Ni}, \mathrm{Pb}$ and $\mathrm{Zn}$ in their free ion forms (Roberts et al., 2013). Low $\mathrm{pH}$ combined with increased availability can influence and increase seagrass uptake of trace elements (Yang and Ye, 2009) that can lead to higher accumulation and storage of trace elements in seagrass roots and leaves (Bonanno and Bonaca, 2017). Higher accumulation can lead to metal stress once threshold levels are reached and affect the seagrass physiological processes (Olive et al., 2017). However, it is difficult to measure toxic effects of metals on seagrass in in-situ conditions due to variable environmental settings, but a few ex-situ studies on metal toxicity have been conducted on Cymodocea serrulata (Prange and Dennison. 2000), Halophila ovalis and H. spinulosa (Prange and Dennison, 2000; AmboRappe et al., 2011). Considering the observed results from these ex-situ metal toxicity studies, there is a possibility that elements such as $\mathrm{Cu}$ and $\mathrm{Pb}$ concentrations at the $\mathrm{CO}_{2}$ seeps may affect $P$. oceanica and $C$. nodosa photosynthesis as well as root and leaf structures (Prange and Dennison. 2000; Ambo -Rapee et al., 2011). This can be one of the reasons due to which seagrasses are abundant at some seeps (e.g. Ischia) but not others (e.g. Vulcano) given that they grow well and can take advantage of elevated $\mathrm{CO}_{2}$ levels at some seeps but not at others (Vizzini et al., 2010; Russell et al., 2013; Olive et al., 2017).

\section{Conclusion:}

To sum up: we observed that Mediterranean $\mathrm{CO}_{2}$ seep sites of Greek and Italy consistently have elevated levels of trace elements in sediments, which can be used to study the interactions between low $\mathrm{pH}$, element bioavailability and element accumulation within seagrasses compartments. We concur with Bary et al., (2011), Vizzini et al., (2013), Lauritano et al., (2015) and Olive et al., (2017) that care is needed when using volcanic $\mathrm{CO}_{2}$ seeps as analogues for the effects of ocean acidification as there can be areas with increased levels of elements that can be harmful to seagrasses. In some cases, such as Ischia, high levels of trace elements available in the sediment, such as $\mathrm{Cu}$ were not accumulated in 
seagrass, whereas in Vulcano, we found that elevated levels of $\mathrm{Zn}$ were accumulated in seagrass roots and rhizomes. Thus, future work that use seep sites to assess the effects of trace element availability and accumulation in seagrass ecosystems can shed light on trace element impacts on seagrass physiology, threshold levels of trace elements and their toxic effects on seagrass and probably define sediment quality guidelines for seagrass and seagrass associated biota (Bouchon et al., 2016) under low pH conditions. The findings of our research are relevant to agencies responsible for monitoring the effects of trace element contamination in the marine environment using seagrass ecosystems, conservation and protection of seagrass ecosystems in the Mediterranean Sea for their ecosystem services.

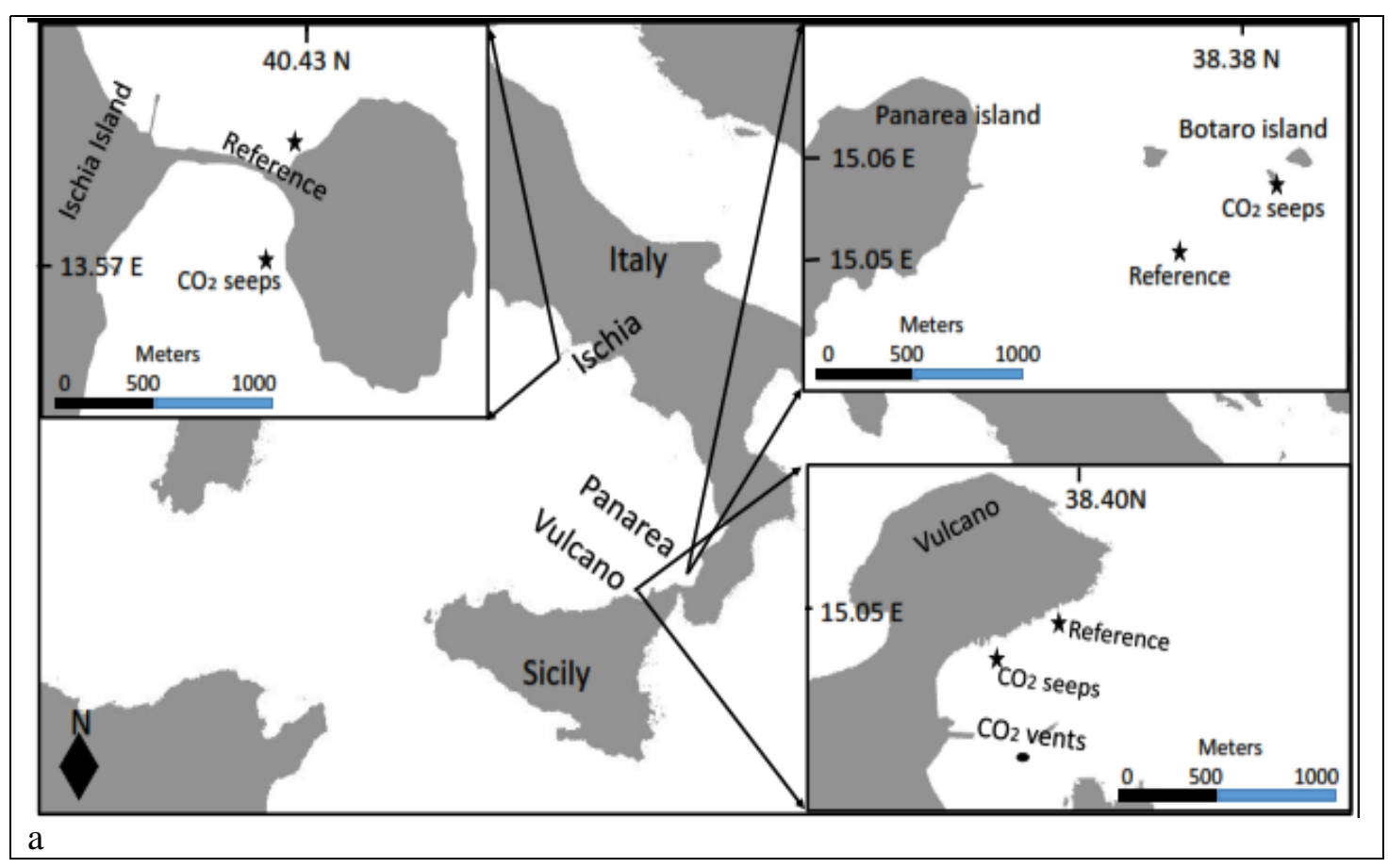




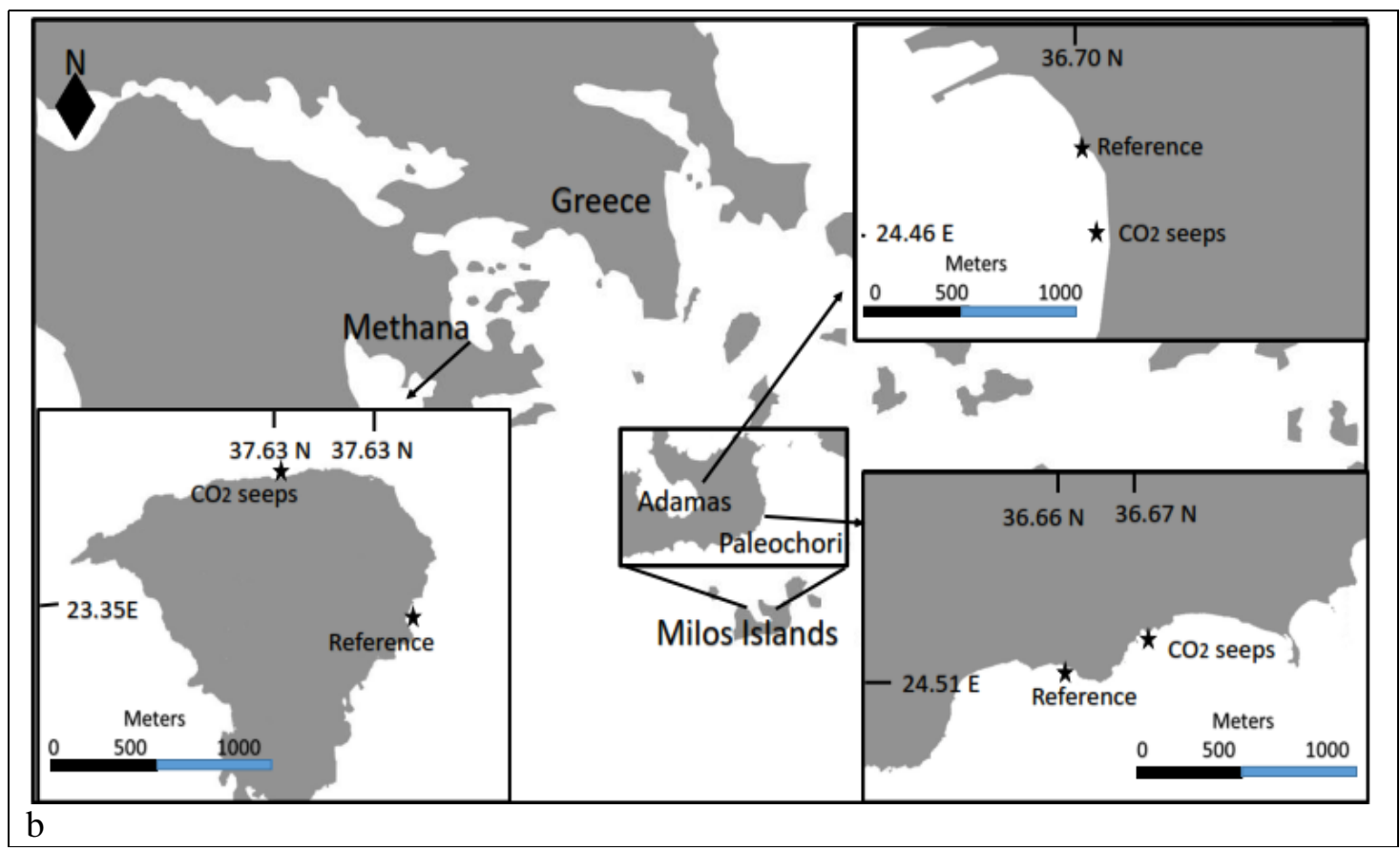

Fig.1. Study sites in Italy a) and b) Greece, showing reference and $\mathrm{CO}_{2}$ seep sites, which were all sampled between May to July 2014.

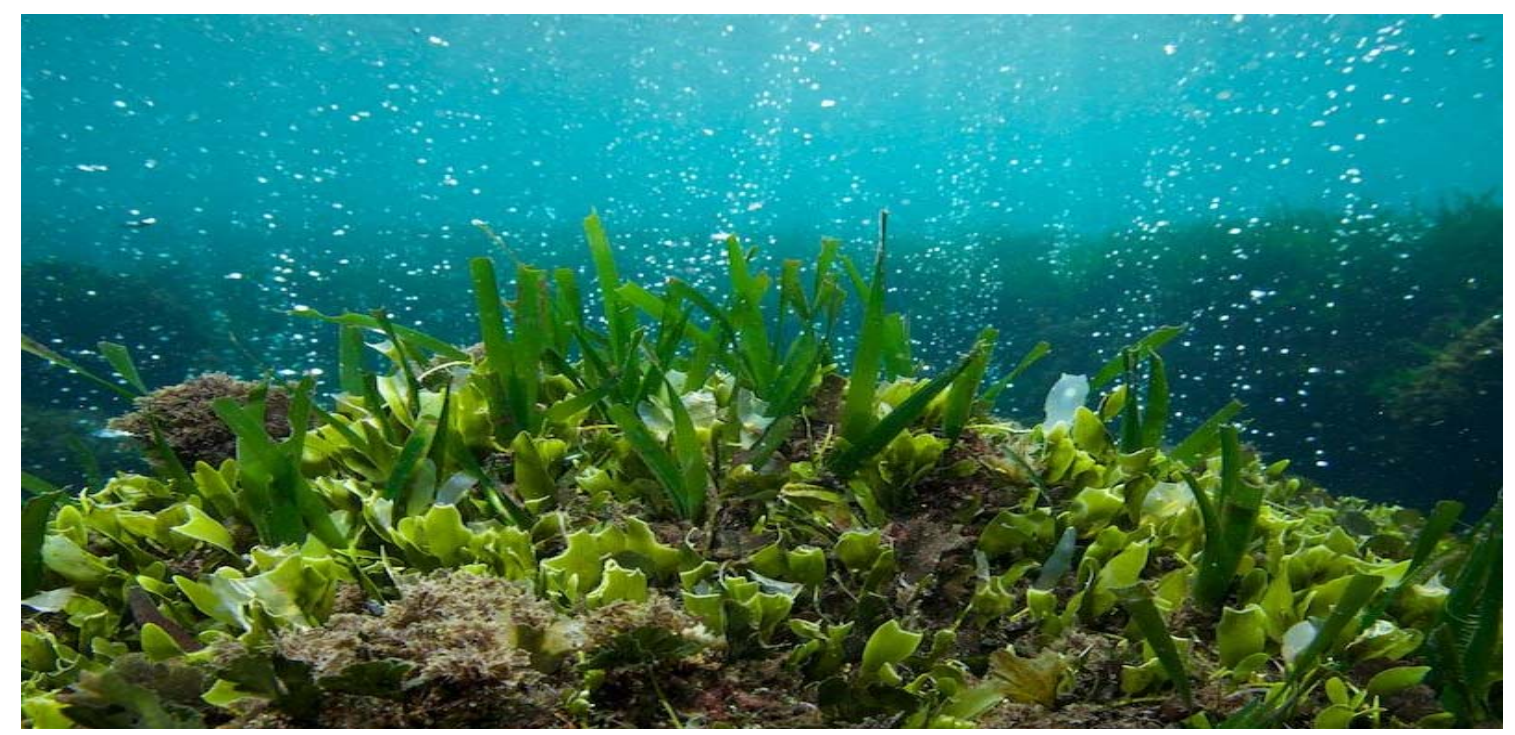




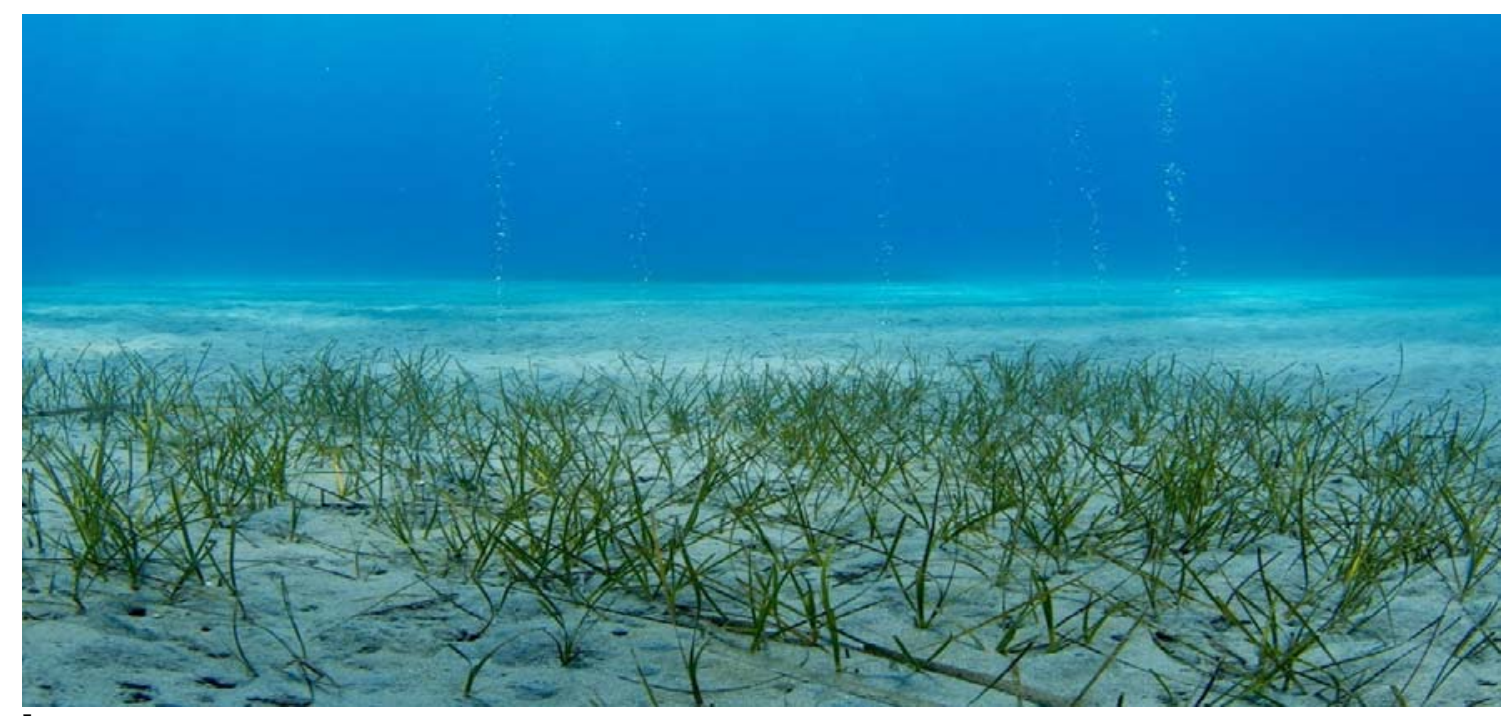

b

Fig. 2. a) Posidonia oceanica and b) Cymodocea nodosa meadows at $\mathrm{CO}_{2}$ seeps off Ischia (Italy) and Paleochori (Greece).

Photo credits for a) Posidonia oceanica, and b) Cymodocea nodosa meadows at Italy and Greece: Jason Hall Spencer, University of Plymouth, UK and Thanos Dailianis of Hellenic Centre for Marine Research, Greece respectively.

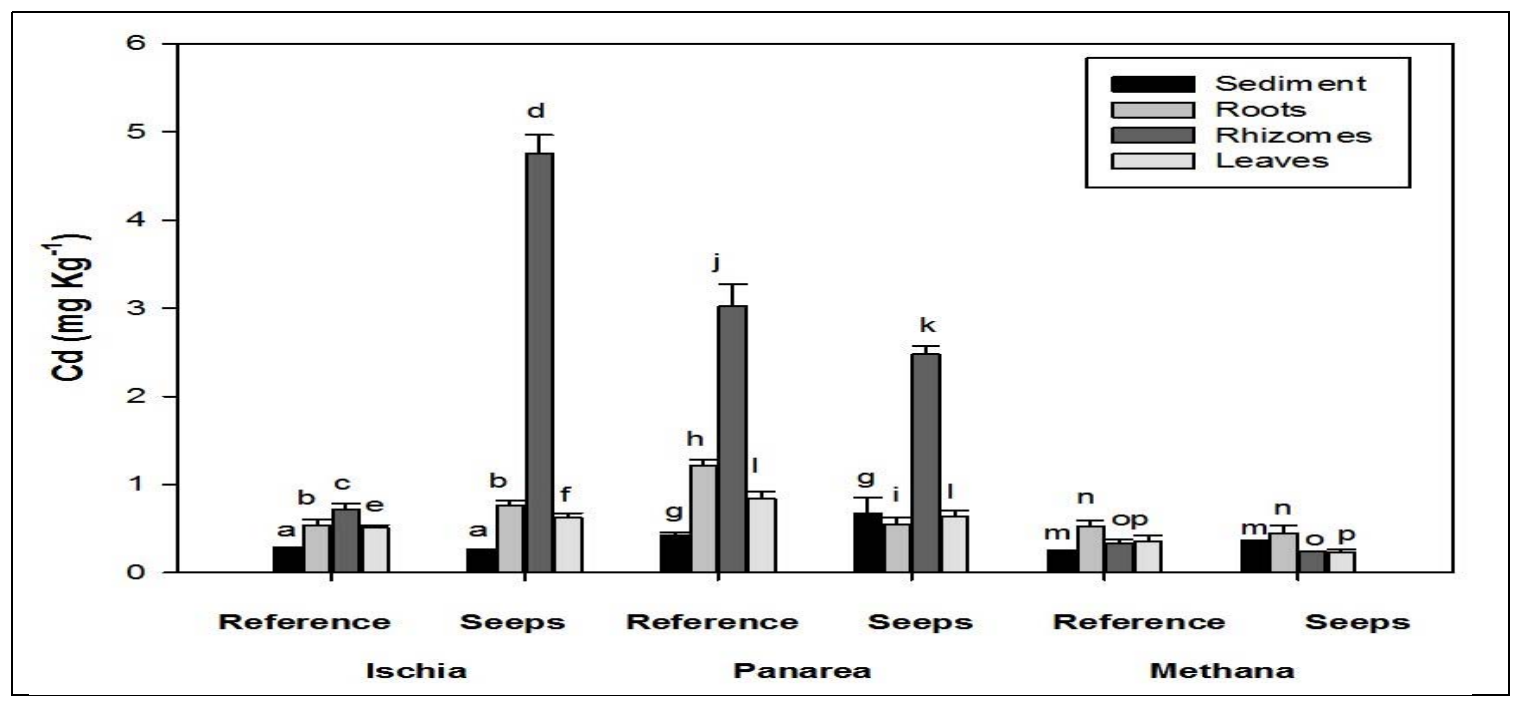




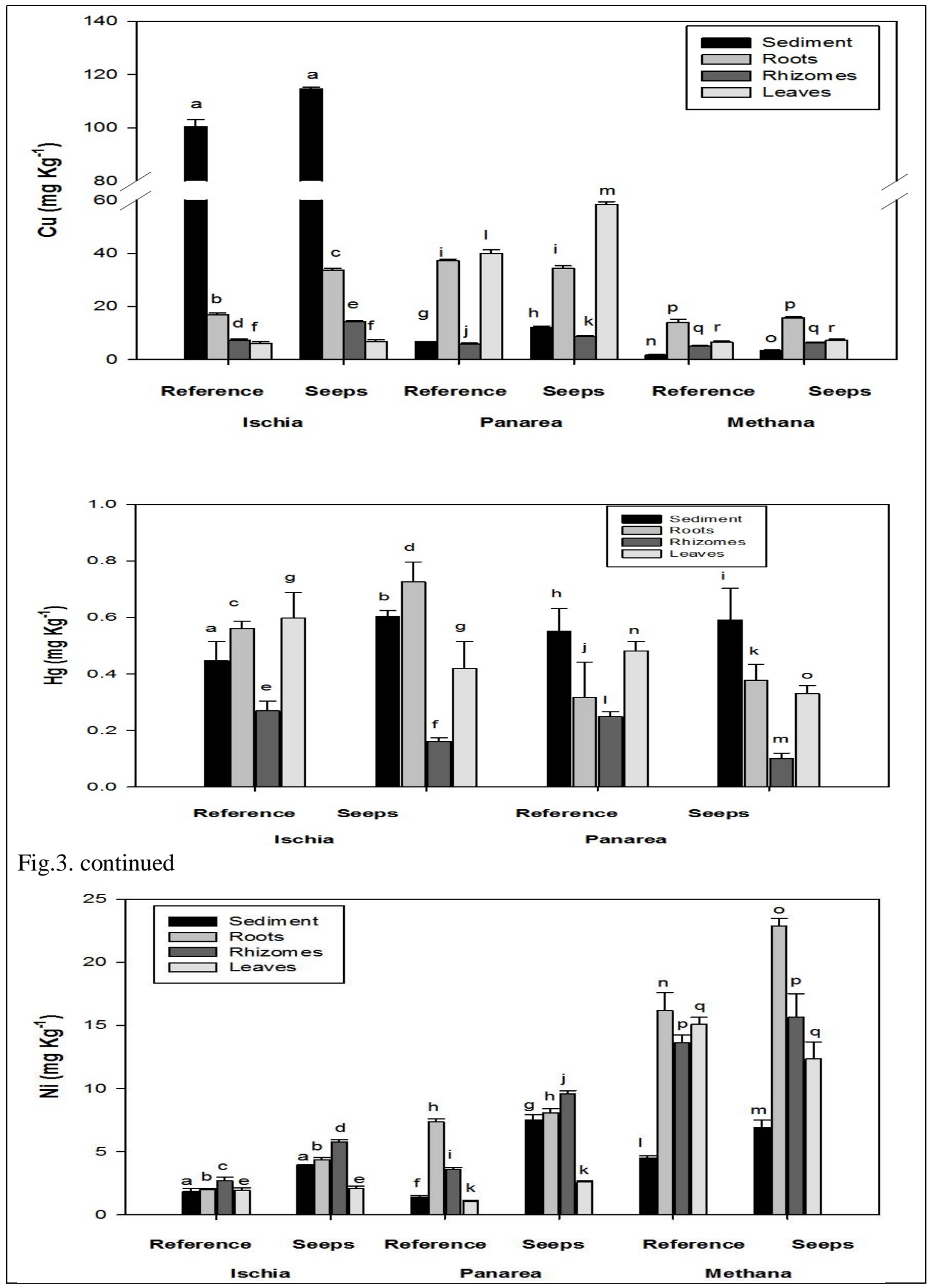




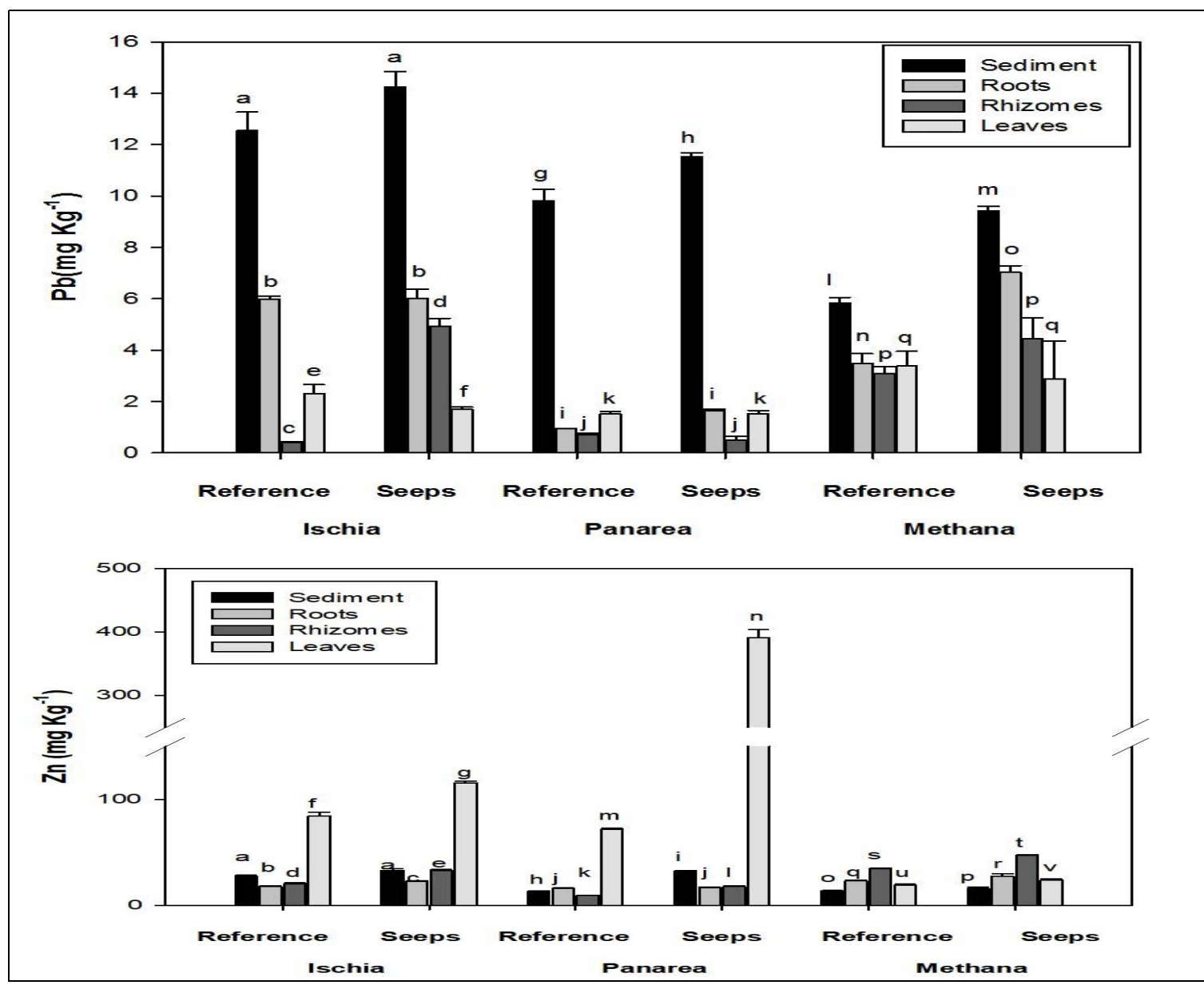

Fig. 3. Element concentrations (mean $\pm \mathrm{SE}, \mathrm{n}=5$ ) of $\mathrm{Cd}, \mathrm{Cu}, \mathrm{Hg}, \mathrm{Ni}, \mathrm{Pb}$ and $\mathrm{Zn}$ in Posidonia oceanica plant compartments and sediments at reference and $\mathrm{CO}_{2}$ seep sites off Italy and Greece. Different letters indicate significant differences between reference and $\mathrm{CO}_{2}$ seeps site at each location.

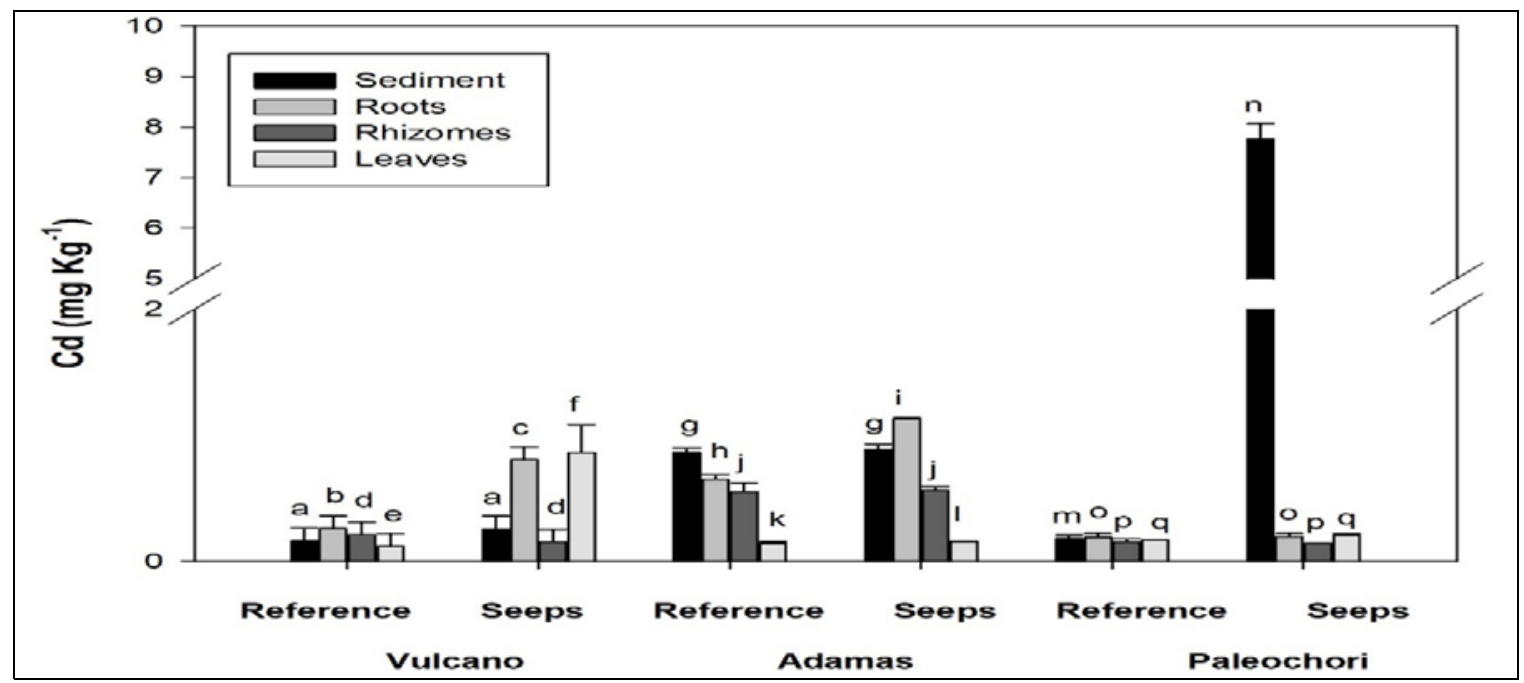




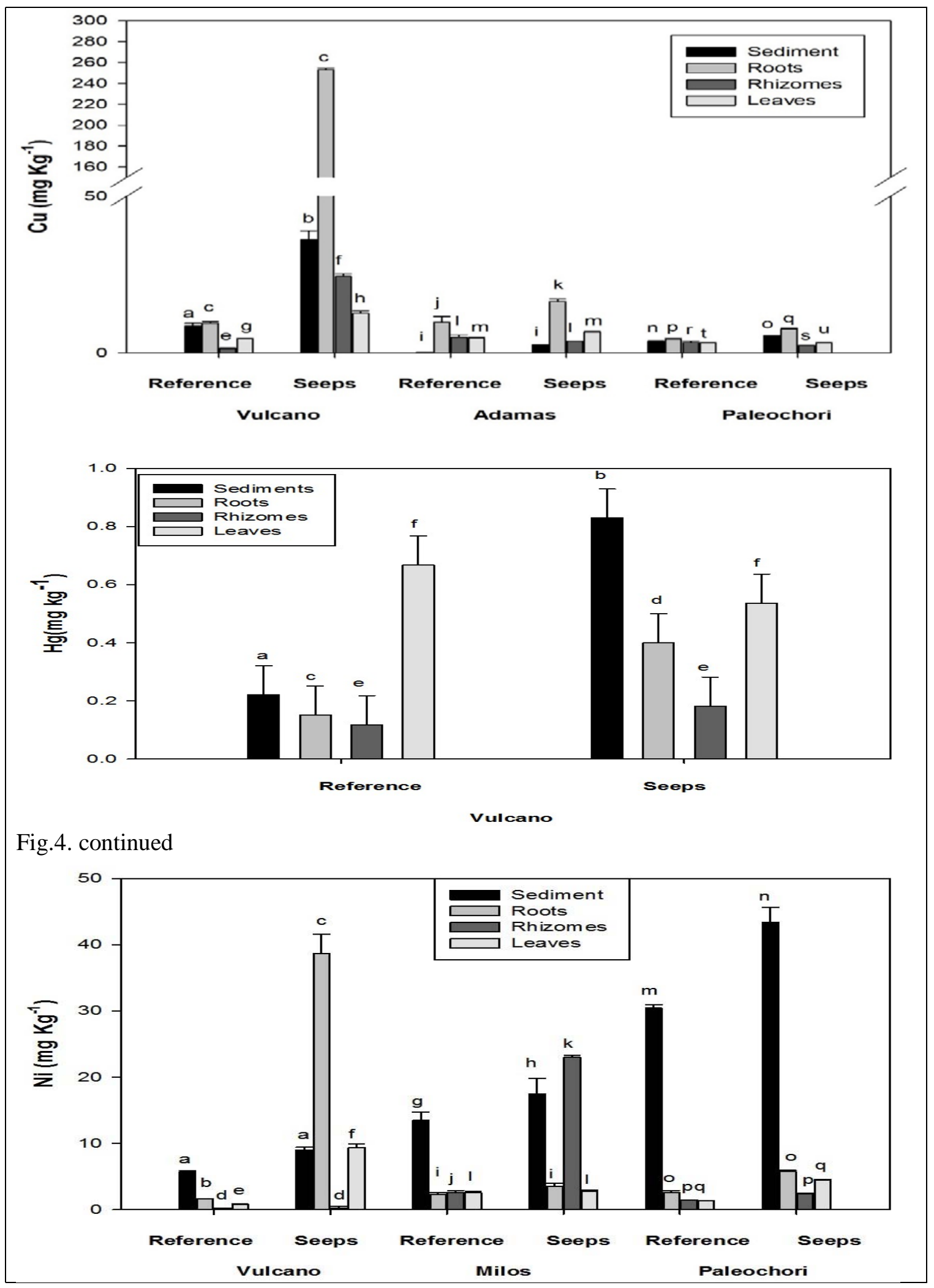




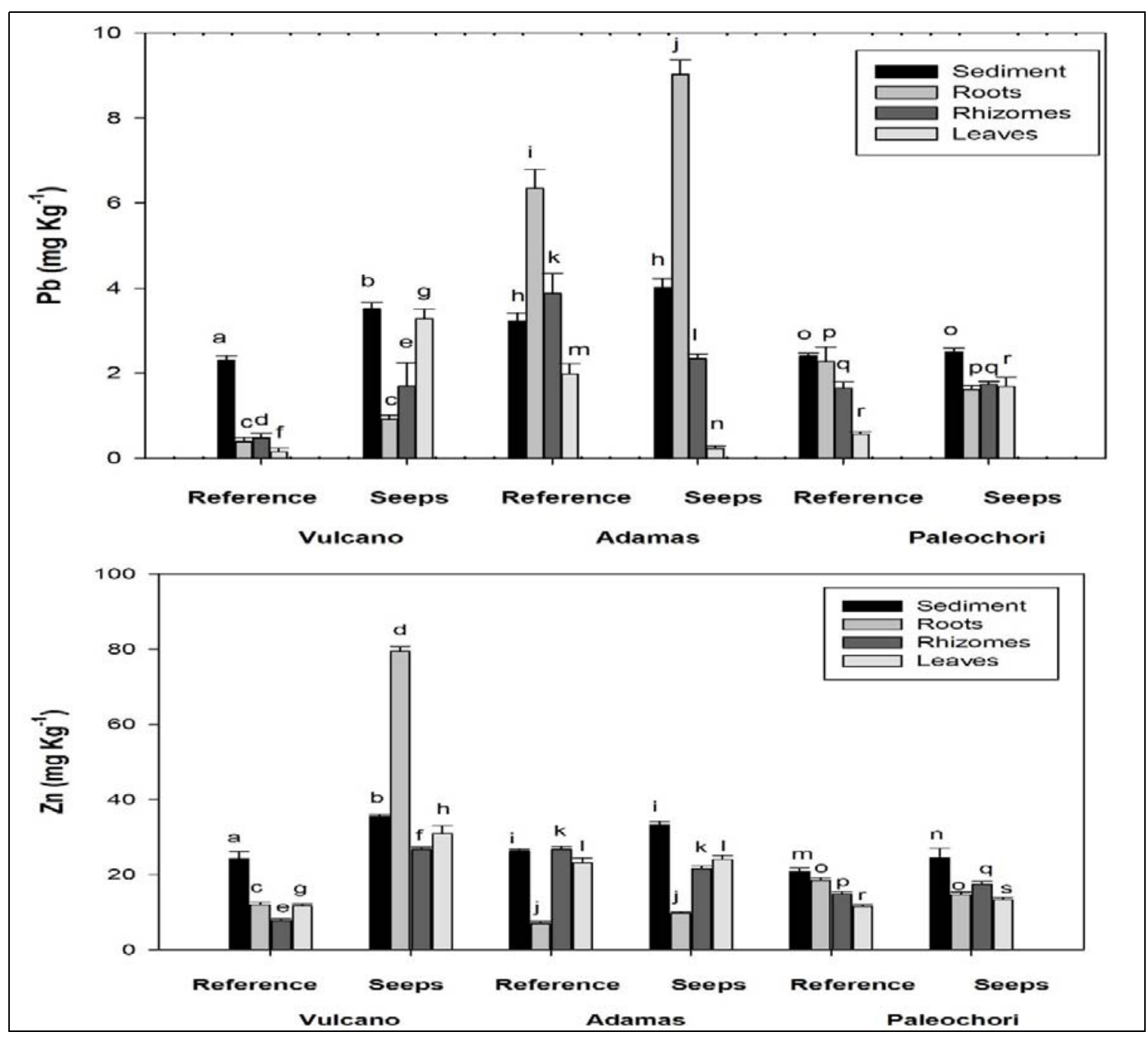

Fig. 4. Element concentration (mean $\pm \mathrm{SE}, \mathrm{n}=5$ ) of $\mathrm{Cd}, \mathrm{Cu}, \mathrm{Hg}, \mathrm{Ni}, \mathrm{Pb}$ and $\mathrm{Zn}$ for Cymodocea nodosa in plant compartments and sediments at reference and $\mathrm{CO}_{2}$ seeps off Italy and Greece. Different letters indicate significant differences between reference and $\mathrm{CO}_{2}$ seep sites for each location.

Table 1: Seawater salinity, temperature, total alkalinity, $\mathrm{pH}$ and $p \mathrm{CO}_{2}$ values (mean $\pm \mathrm{SE}$, $\mathrm{n}=5$ ) at six Mediterranean $\mathrm{CO}_{2}$ seeps and reference sites between May-July 2014. 


\begin{tabular}{|c|c|c|c|c|c|}
\hline Site & $\begin{array}{l}\text { Salinity } \\
\text { (psu) }\end{array}$ & Temp. $\left({ }^{\circ} \mathrm{C}\right)$ & $\mathbf{p H}_{\mathrm{NBS}}$ & $\begin{array}{l}\text { TA }(\mu \mathrm{mol} \\
\left.\mathrm{Kg} \mathrm{SW}^{-1}\right)\end{array}$ & $p \mathrm{CO}_{2}$ \\
\hline \multicolumn{6}{|l|}{ Vulcano } \\
\hline Reference & 35.8 & 21.6 & $8.17 \pm 0.05$ & 2439 & $427 \pm 6.8$ \\
\hline $\mathrm{CO}_{2}$ seep & 35.8 & 22.4 & $7.98 \pm 0.08$ & 2432 & $2928 \pm 15.8$ \\
\hline \multicolumn{6}{|l|}{ Ischia } \\
\hline Reference & 35.6 & 17.7 & $8.19 \pm 0.06$ & 2596 & $428 \pm 2.3$ \\
\hline $\mathrm{CO}_{2}$ seep & 35.7 & 17.8 & $7.78 \pm 0.05$ & 2589 & $1653 \pm 10.2$ \\
\hline \multicolumn{6}{|l|}{ Panarea } \\
\hline Reference & 36.0 & 20.5 & $8.18 \pm 0.05$ & 2507 & $420 \pm 4.6$ \\
\hline $\mathrm{CO}_{2}$ seep & 36.0 & 22.3 & $7.47 \pm 0.04$ & 2500 & $3370 \pm 2.3$ \\
\hline \multicolumn{6}{|l|}{ Adamas } \\
\hline Reference & 36.7 & 22.6 & $8.2 \pm 0.03$ & 2715 & $405.5 \pm 1.6$ \\
\hline $\mathrm{CO}_{2}$ seep & 36.7 & 23.5 & $7.5 \pm 0.04$ & 2704 & $\begin{array}{l}2457.9 \pm \\
1.8\end{array}$ \\
\hline \multicolumn{6}{|l|}{ Paleochori } \\
\hline Reference & 36.0 & 22.6 & $8.2 \pm 0.01$ & 2711 & $402.9 \pm 1.1$ \\
\hline $\mathrm{CO}_{2}$ seep & 36.0 & 22.8 & $7.9 \pm 0.01$ & 2706 & $\begin{array}{l}1884.3 \pm \\
3.0\end{array}$ \\
\hline \multicolumn{6}{|l|}{ Methana } \\
\hline Reference & 36.8 & 22.8 & $8.2 \pm 0.01$ & 2715 & $460 \pm 6.9$ \\
\hline $\mathrm{CO}_{2}$ seep & 36.8 & 23.0 & $7.8 \pm 0.02$ & 2704 & $1980 \pm 4.4$ \\
\hline
\end{tabular}


Table 2. Sediment Quality Guidelines-quotient (SQG-Q) of sediment calculated with Probable Effects Level for Reference and $\mathrm{CO}_{2}$ seep sites in Greece and Italy. SQG-Q $<0.1$ (low effect), <0.1 SQG-Q>1 (moderate effect), SQG-Q>1 (adverse biological effects). Numbers in bold indicate possible adverse effects of trace elements.

\begin{tabular}{|c|c|c|c|c|c|}
\hline \multirow[b]{2}{*}{ Location } & \multirow[b]{2}{*}{ Element } & \multirow{2}{*}{$\begin{array}{l}\text { SQG-Q } \\
\text { Reference }\end{array}$} & \multirow[b]{2}{*}{$\mathrm{CO}_{2}$ seeps } & \multirow{2}{*}{$\begin{array}{l}\text { Effects } \\
\text { Reference }\end{array}$} & \multirow[b]{2}{*}{$\mathrm{CO}_{2}$ seeps } \\
\hline & & & & & \\
\hline \multirow[t]{4}{*}{ Vulcano } & $\mathrm{Cu}$ & 0.08 & 0.33 & Low & Moderate \\
\hline & $\mathrm{Hg}$ & 0.32 & 1.18 & Moderate & Adverse \\
\hline & $\mathrm{Ni}$ & 0.13 & 0.21 & Moderate & Moderate \\
\hline & $\mathrm{Zn}$ & 0.09 & 0.13 & Low & Moderate \\
\hline \multirow[t]{4}{*}{ Ischia } & $\mathrm{Cu}$ & 0.93 & 1.06 & Moderate & Adverse \\
\hline & $\mathrm{Hg}$ & 0.64 & 0.86 & Moderate & Moderate \\
\hline & $\mathrm{Pb}$ & 0.11 & 0.13 & Moderate & Moderate \\
\hline & $\mathrm{Zn}$ & 0.12 & 0.10 & Moderate & Moderate \\
\hline \multirow[t]{6}{*}{ Panarea } & $\mathrm{Cd}$ & 0.10 & 0.16 & Low & Moderate \\
\hline & $\mathrm{Cu}$ & 0.06 & 0.11 & Low & Moderate \\
\hline & $\mathrm{Hg}$ & 0.79 & 0.84 & Moderate & Moderate \\
\hline & $\mathrm{Ni}$ & 0.03 & 0.18 & Low & Moderate \\
\hline & $\mathrm{Pb}$ & 0.09 & 0.57 & Low & Moderate \\
\hline & $\mathrm{Zn}$ & 0.05 & 0.12 & Low & Moderate \\
\hline \multirow[t]{2}{*}{ Adamas } & $\mathrm{Cd}$ & 0.21 & 0.21 & Moderate & Moderate \\
\hline & $\mathrm{Ni}$ & 0.31 & 0.41 & Moderate & Moderate \\
\hline \multirow[t]{2}{*}{ Paleochori } & $\mathrm{Cd}$ & 0.04 & 1.84 & Low & Adverse \\
\hline & $\mathrm{Ni}$ & 0.71 & 1.01 & Moderate & Adverse \\
\hline \multirow[t]{2}{*}{ Methana } & $\mathrm{Ni}$ & 0.11 & 0.16 & Moderate & Moderate \\
\hline & $\mathrm{Pb}$ & 0.05 & 0.42 & Low & Moderate \\
\hline
\end{tabular}


Table 3. Three-way ANOVA differences in Fe and trace element levels between Location: 3 levels (Methana (M), Panarea(P) and Ischia (V)), Site:2 variables $\left(\mathrm{CO}_{2}\right.$ seeps, Reference)) and compartments :4 levels (Sediments (Sd), Rhizomes (Rh), Roots (R), Leaves (L)). Holm-Sidak significant test $(\mathrm{p}<0.05)$ is presented for locations, sediment and $P$. oceanica compartments. Numbers (in bold) indicate differences that were not significant.

\begin{tabular}{|c|c|c|c|c|c|c|c|c|c|c|c|}
\hline \multirow[b]{3}{*}{ Element } & \multirow[b]{3}{*}{ Variation } & \multirow[b]{3}{*}{ p value } & \multicolumn{3}{|c|}{ Holm-Sidak p values } & \multirow{2}{*}{\multicolumn{3}{|c|}{ Sediment vs Compartment }} & \multirow{2}{*}{\multicolumn{2}{|c|}{ Compartments }} & \multirow[b]{3}{*}{$\mathbf{R}$ vs $\mathbf{L}$} \\
\hline & & & \multicolumn{2}{|c|}{ Location } & \multirow[b]{2}{*}{ V vs P } & & & & & & \\
\hline & & & M vs P & M vs V & & Sd vs R & Sd vs Rh & Sd vs L & R vs Rh & $\begin{array}{l}\text { Rh vs } \\
\text { L }\end{array}$ & \\
\hline \multirow[t]{3}{*}{$\mathrm{Fe}$} & Site & $<0.001$ & $<0.001$ & $<0.001$ & $<0.001$ & & & & & & \\
\hline & Station & $<0.001$ & & & & & & & & & \\
\hline & Compt. & $<0.001$ & & & & $<0.001$ & $<0.001$ & $<0.001$ & $<0.001$ & $<0.001$ & $<0.001$ \\
\hline \multirow[t]{3}{*}{$\mathrm{Cd}$} & Site & $<0.001$ & $<0.001$ & $<0.001$ & $<0.001$ & & & & & & \\
\hline & Station & $<0.001$ & & & & & & & & & \\
\hline & Compt. & $<0.001$ & & & & $<0.001$ & $<0.001$ & $<0.001$ & $<0.001$ & $<0.001$ & $<0.001$ \\
\hline \multirow[t]{3}{*}{$\mathrm{Cu}$} & Site & $<0.001$ & $<0.001$ & $<0.001$ & $<0.001$ & & & & & & \\
\hline & Station & $<0.001$ & & & & & & & & & \\
\hline & Compt. & $<0.001$ & & & & $<0.001$ & $<0.001$ & 0.314 & $<0.001$ & $<0.001$ & $<0.001$ \\
\hline \multirow[t]{3}{*}{$\mathrm{Ni}$} & Site & $<0.001$ & $<0.001$ & $<0.001$ & $<0.001$ & & & & & & \\
\hline & Station & $<0.001$ & & & & & & & & & \\
\hline & Compt. & $<0.001$ & & & & $<0.001$ & $<0.001$ & $<0.001$ & $<0.001$ & $<0.001$ & $<0.001$ \\
\hline \multirow[t]{3}{*}{$\mathrm{Pb}$} & Site & $<0.001$ & $<0.001$ & $<0.001$ & $<0.001$ & & & & & & \\
\hline & Station & $<0.001$ & & & & & & & & & \\
\hline & Compt. & $<0.001$ & & & & $<0.001$ & $<0.001$ & $<0.001$ & $<0.001$ & $<0.001$ & 0.652 \\
\hline \multirow[t]{3}{*}{$\mathrm{Zn}$} & Site & $<0.001$ & $<0.001$ & $<0.001$ & $<0.001$ & & & & & & \\
\hline & Station & $<0.001$ & & & & & & & & & \\
\hline & Compt. & $<0.001$ & & & & 0.222 & $<0.001$ & $<0.001$ & $<0.001$ & $<0.001$ & $<0.001$ \\
\hline
\end{tabular}


Table 4. Three-way ANOVA differences in Fe and trace element levels between Location: 3 levels (Adamas (A), Paleochori (P) and Vulcano (V)), Sites:2 variables ( $\mathrm{CO}_{2}$ seeps, reference) and compartments: 4 levels (Sediments (Sd), Rhizomes (Rh), Roots (R), Leaves (L). Holm-Sidak significant test $(\mathrm{p}<0.05)$ is presented for locations, sediment and $C$. nodosa compartments. Numbers (in bold) indicate differences that were not significant.

\begin{tabular}{|c|c|c|c|c|c|c|c|c|c|c|c|}
\hline \multirow[b]{3}{*}{ Element } & \multirow[b]{3}{*}{ Variation } & \multirow[b]{3}{*}{ p value } & \multicolumn{3}{|c|}{ Holm-Sidak p values } & \multirow{2}{*}{\multicolumn{3}{|c|}{ Sediment vs Compartment }} & \multirow{2}{*}{\multicolumn{2}{|c|}{ Compartments }} & \multirow[b]{3}{*}{ R vs $\mathbf{L}$} \\
\hline & & & \multicolumn{2}{|c|}{ Location } & \multirow[b]{2}{*}{ V vs $P$} & & & & & & \\
\hline & & & A vs P & A vs V & & Sd vs $R$ & Sd vs Rh & Sd vs L & R vs Rh & Rh vs L & \\
\hline \multirow[t]{3}{*}{$\mathrm{Fe}$} & Site & $<0.001$ & $<0.001$ & $<0.001$ & $<0.001$ & & & & & & \\
\hline & Station & $<0.001$ & & & & & & & & & \\
\hline & Compt. & $<0.001$ & & & & $<0.001$ & $<0.001$ & $<0.001$ & $<0.001$ & $<0.001$ & $<0.001$ \\
\hline \multirow[t]{3}{*}{$\mathrm{Cd}$} & Site & $<0.001$ & $<0.001$ & $<0.001$ & $<0.001$ & & & & & & \\
\hline & Station & $<0.001$ & & & & & & & & & \\
\hline & Compt. & $<0.001$ & & & & $<0.001$ & $<0.001$ & $<0.001$ & $<0.001$ & 0.787 & $<0.001$ \\
\hline \multirow[t]{3}{*}{$\mathrm{Cu}$} & Site & $<0.001$ & 0.626 & $<0.001$ & $<0.001$ & & & & & & \\
\hline & Station & $<0.001$ & & & & & & & & & \\
\hline & Compt. & $<0.001$ & & & & $<0.001$ & 0.621 & $<0.001$ & $<0.001$ & $<0.001$ & $<0.001$ \\
\hline \multirow[t]{3}{*}{$\mathrm{Ni}$} & Site & $<0.001$ & $<0.001$ & 0.853 & $<0.001$ & & & & & & \\
\hline & Station & $<0.001$ & & & & & & & & & \\
\hline & Compt. & $<0.001$ & & & & $<0.001$ & $<0.001$ & $<0.001$ & $<0.001$ & $<0.001$ & $<0.001$ \\
\hline \multirow[t]{3}{*}{$\mathrm{Zn}$} & Site & $<0.001$ & $<0.001$ & $<0.001$ & $<0.001$ & & & & & & \\
\hline & Station & $<0.001$ & & & & & & & & & \\
\hline & Compt. & $<0.001$ & & & & $<0.001$ & $<0.001$ & $<0.001$ & $<0.001$ & 0.910 & $<0.001$ \\
\hline
\end{tabular}


Table 5. Correlation between trace elements in sediments versus $P$. oceanica roots, rhizomes and leaves and plant compartments at Mediterranean $\mathrm{CO}_{2}$ seeps. The correlation coefficient (r) and significance level (p) are presented. Numbers in bold indicate significant correlation, only trace elements with significant correlations are shown.

\begin{tabular}{|c|c|c|c|c|c|c|c|}
\hline \multirow[b]{2}{*}{ Location } & \multirow[b]{2}{*}{ Element } & \multicolumn{2}{|c|}{ Sediment-roots } & \multicolumn{2}{|c|}{ Sediment-rhizomes } & \multicolumn{2}{|c|}{ Sediment-Leaves } \\
\hline & & $\mathrm{r}$ & $\mathrm{p}$ & $\mathrm{r}$ & $\mathrm{p}$ & $\mathrm{r}$ & $\mathrm{p}$ \\
\hline Ischia & $\mathrm{Zn}$ & -0.234 & 0.704 & 0.870 & 0.048 & 0.321 & 0.598 \\
\hline \multirow[t]{4}{*}{ Panarea } & $\mathrm{Cd}$ & 0.841 & 0.014 & -0.910 & 0.032 & -0.064 & 0.918 \\
\hline & $\mathrm{Ni}$ & -0.358 & 0.554 & 0.884 & 0.046 & -0.787 & 0.114 \\
\hline & \multicolumn{7}{|c|}{ Seagrass compartments } \\
\hline & & \multicolumn{2}{|c|}{ Roots-Rhizomes } & \multicolumn{2}{|c|}{ Roots-Leaves } & \multicolumn{2}{|c|}{ Rhizomes-Leaves } \\
\hline \multirow[t]{2}{*}{ Ischia } & $\mathrm{Cd}$ & 0.300 & 0.683 & 0.975 & 0.016 & 0.359 & 0.517 \\
\hline & $\mathrm{Cu}$ & -0.273 & 0.657 & 0.877 & 0.049 & -0.577 & 0.308 \\
\hline
\end{tabular}

Table 6. Correlation between trace elements in sediment versus C. nodosa roots, rhizomes and leaves and between plant compartments at Mediterranean $\mathrm{CO}_{2}$ seeps. The correlation coefficient (r) and significance (p) level are presented. Numbers in bold indicate significant correlations, only trace elements with significant co-relation are shown.

\begin{tabular}{|c|c|c|c|c|c|c|c|}
\hline \multirow[b]{2}{*}{ Location } & \multirow[b]{2}{*}{ Element } & \multicolumn{2}{|c|}{ Sediment-roots } & \multicolumn{2}{|c|}{ Sediment-rhizomes } & \multicolumn{2}{|c|}{ Sediment-Leaves } \\
\hline & & $\mathrm{r}$ & $\mathrm{p}$ & $\mathrm{r}$ & $\mathrm{p}$ & $\mathrm{r}$ & $\mathrm{p}$ \\
\hline \multirow[t]{4}{*}{ Vulcano } & $\mathrm{Fe}$ & 0.437 & 0.462 & 0.992 & 0.000 & -0.836 & 0.078 \\
\hline & $\mathrm{Zn}$ & -0.795 & 0.108 & -0.966 & 0.007 & -0.906 & 0.034 \\
\hline & & \multicolumn{4}{|c|}{ Seagrass Compartments } & & \\
\hline & & \multicolumn{2}{|c|}{ Roots-Rhizomes } & \multicolumn{2}{|c|}{ Rhizomes-Leaves } & \multicolumn{2}{|c|}{ Roots-Leaves } \\
\hline \multirow[t]{3}{*}{ Vulcano } & $\mathrm{Cd}$ & 1.000 & 0.016 & 0.158 & 0.783 & 0.158 & 0.783 \\
\hline & $\mathrm{Cu}$ & -0.986 & 0.002 & 0.534 & 0.354 & -0.620 & 0.265 \\
\hline & $\mathrm{Hg}$ & -0.135 & 0.783 & 0.216 & 0.683 & -0.947 & 0.016 \\
\hline \multirow[t]{2}{*}{ Adamas } & $\mathrm{Fe}$ & -0.975 & 0.016 & -0.300 & 0.683 & 0.205 & 0.683 \\
\hline & $\mathrm{Cu}$ & -0.872 & 0.083 & -1.000 & 0.016 & 0.872 & 0.083 \\
\hline
\end{tabular}


Table 7. Mean range of trace element $(\mathrm{mg} / \mathrm{Kg})$ levels measured in surface sediments and in $P$. oceanica and $C$. nodosa compartments (roots, rhizomes and leaves) off Italy and Greek coast in Mediterranean Sea.

\begin{tabular}{|c|c|c|c|c|c|c|c|c|}
\hline Sample & Location & Tissues & Cd & $\mathbf{C u}$ & Hg & $\mathbf{N i}$ & $\mathbf{P b}$ & $\mathbf{Z n}$ \\
\hline \multirow{2}{*}{ Sediment } & Italy & & $0.21-1.92$ & $14.92-55.52$ & $0.61-2.57$ & $13.26-201.45$ & $23.67-45.46$ & $49.48-76.81$ \\
\hline & Greek & & $0.22-43.57$ & $30.64-204$ & $0.05-0.39$ & 42.20 & $55.42-309$ & $128-225.60$ \\
\hline \multirow[t]{6}{*}{ P. oceanica } & Italy & Leaf & $1.17-3.16$ & $6.97-16.17$ & $0.06-0.11$ & $16.01-55.08$ & $2.25-6.43$ & $113.02-203.38$ \\
\hline & & Rhizome & $0.55-1.51$ & $8.37-21.37$ & $0.08-0.11$ & $3.82-8.29$ & $3.19-10.50$ & $54.41-171$ \\
\hline & & Root & $0.70-1.23$ & $13.33-17.40$ & $0.21-0.34$ & $6.20-8.56$ & $4.94-9.63$ & $65.86-119.67$ \\
\hline & Greek & Leaf & 6.52 & $9.66-45-80$ & 0.07 & $18.45-60.90$ & 15.61 & 88.20 \\
\hline & & Rhizome & 0.53 & $2.75-58.6$ & - & $13.17-46.20$ & 15.20 & 59.88 \\
\hline & & Root & 0.74 & $5.37-36.10$ & - & $7.27-46.21$ & 43.10 & 55.67 \\
\hline \multirow[t]{6}{*}{ C. nodosa } & Italy & Leaf & $0.28-2.73$ & $7.30-28.81$ & $0.27-2.23$ & $3.84-6.65$ & $2.61-23.56$ & $48.8-65-8$ \\
\hline & & Rhizome & $0.05-0.22$ & $5.69-23.1$ & 0.13 & $1.52-5.34$ & $0.45-1.87$ & $21.15-31.17$ \\
\hline & & Root & $0.22-0.45$ & $6.57-25-8$ & 0.19 & $4.05-7.89$ & $4.58-6.99$ & $37.25-50.44$ \\
\hline & Greek & Leaf & $0.70-0.79$ & $7.75-59.60$ & - & $3.40-27.03$ & $108-210$ & $87.27-627$ \\
\hline & & Rhizome & $0.89-0.44$ & $4.95-17.65$ & - & $0.90-6.11$ & $117-220$ & $45.47-77.70$ \\
\hline & & Root & $0.89-0.44$ & $7.58-49.80$ & - & $2.28-19.43$ & $113.50-220$ & $34-77$ \\
\hline
\end{tabular}




\section{Acknowledgement:}

This work was part of MARES "Future Oceans" project (MARES _12_14) and was funded through a MARES Grant. MARES is a Joint Doctorate programme selected under Erasmus Mundus coordinated by Ghent University (FPA 2011-0016). Check www.mares-eu.org for extra information. We are grateful to Dr Marco Milazzo for his support during the field work at Vulcano, Italy. Dr Joao Silva and Dr Irene Oliva for helping me collect samples form Ischia and Panarea, Italy. We are grateful for the support of Thanos Dailianis, Julius Glampedakis in collection of samples from Greece and Dr Eugenia Apostolaki for her support during the field work. I am thankful to Andrew Tonkin and Robert Clough at Plymouth University, UK for helping me in the laboratory analysis. We would like to thank Prof. Paul Dando and Prof. Franceso Parello for their constructive comments on an early draft.

\section{References}

Ahmad, F., Azman, S., Savid, M.I.M., Baloo, L., 2015. Tropical seagrass as bioindicator of metal accumulation. Sains Malaysiana.44: 203-210

Aiuppa, A., Dongarrà, G., Capasso, G., Allard, P., 2000. Trace elements in the thermal ground waters of Vulcano Island (Sicily). J. of Volcanol. Geotherm. Res. 98:189- 207

Alloway, B. J.: Heavy Metals in Soils, Blackie Academic \& Professional, Glasgow, 1995

Ambo Rappe, R, Lajus, D.L, Schreider, M.J., 2007. Translational fluctuating asymmetry and leaf dimension in seagrass, Zostera capricorni Aschers in a gradient of heavy metals. Environ. Bioindic., 2: 99-116.

Ambo-Rappe, R., Lajus, D.L., Schreider, M.J., 2011. Heavy metal impact on growth and leaf asymmetry of seagrass Halophila ovalis. Jour. Of. Environ. Chem. and Ecotox. 6:145-149

Apostolaki E.T., Vizzini, S., Hendriks, I.E., Olsen, Y.S., 2014. Seagrass ecosystem response to long-term high $\mathrm{CO}_{2}$ in a Mediterranean volcanic vent. Mar. Environ. Res. 99: 9-15

Atkinson, C.A., Jolley, D.F., Simpson, S.L., 2007. Effect of overlying water pH, dissolved oxygen, salinity and sediment disturbances on metal release and sequestration from metal contaminated marine sediments. Chemosphere. 9: 1428-1437

Baggini, C., Salomidi, M., Voutsinas, E., Bray, L., et al., 2014. Seasonality affects Macroalgal Community Response to Increases in $p \mathrm{CO}_{2}$. PLOS one. 9: 1-13

Barry, J.P., Hall-Spencer, J.M., Tyrrell, T., 2010. In situ perturbation experiments: natural venting site, spatial/temporal gradients in ocean $\mathrm{pH}$, manipulative in situ $\mathrm{pCO}_{2}$ perturbations. In: Riebesell, U., Fabry, V.J., Hansson, L., Gattuso, J.-P. (Eds.), Guide to Best Practices for Ocean Acidification Research and Data Reporting. Publications Office of the European Union, Luxembourg, pp. 123-136.

Basallote, M.D., De Orte, M.D., Angel Del Valls, T., Riba, I., 2014. Studying the effect of $\mathrm{CO}_{2}$ induced acidification on sediment toxicity using Acute Amphipod Toxicity Test. Environ. Sci. and Tech. 48: 8864-8872. 
Batley, G.E., Apte, S.C., Stauber, J.L., 2004. Speciation and bioavailability of trace metals in water: Progress since 1982. Australia. J. of Chem. 57: 903- 919

Besar, S.N.T., Shazili, N.A.M., Abdullah, S.A., Mamat, A.S., 2008. Experimental and field study on accumulation of heavy metals. J. Sustainable Management. 3: 41-73

Blott, S.J. and Pye, K., 2001. GRADISTAT: a grain size distribution and statistics package for the analysis of unconsolidated sediments. Earth Surface Process and Landfarming. 26: $1237-1248$

Boatta, F., D’Alessandro, W., Gagliano, A.L., Liotta, et al., 2013. Geochemical survey of Levante bay, Vulcano island (Italy), a natural laboratory for the study of ocean acidification. Mar. Pollut. Bull. 73: 485-494

Bonanno, G., Di Martino, V., 2016. Seagrass Cymodocea nodosa as a trace element bio monitor: Bioaccumulation patterns and biomonitoring uses. J. Geochem. Explor. 169: 43-49.

Bonanno, G., Orlando-Bonaca, M., 2017. Trace element in Mediterranean seagrasses: Accumulation, tolerance and biomonitoring. A review. Mar. Pollut. Bull. 125: 8-18.

Bonanno, G., Raccuia, S.A., 2018. Seagrass Halophila stipulacea: Capacity of accumulation and biomonitoring of trace elements. Sci. Total Environ. 633:257-263.

Bouchon, C., Lemoine, S., Dromard, C., Bouchon-Navarao, C., 2016. Level of contamination by metallic trace elements and organic molecules in the seagrass beds of Guadeloupe Island. Environ. Sci. Pollut. Res. 72: 23-61

Bravo, I., Focaracci, F., Cerfolli, F., Papetti, P., 2016. Relationships between trace elements in Posidonia oceanica shoots and in sediment fractions along Latium coasts (north western Mediterranean Sea). Env. Mont. Assess. 3:157-188. doi 10.1007/s10661-016-5122-9

Brodie, J., Williamson, C., Smale, D.A., Kamenos, N.A., et al.,2014. The future of the northeast Atlantic benthic flora in a high $\mathrm{CO}_{2}$ world. Ecol. Evol.13: 2787-2798.

Byrne et al. 1988. The influence of temperature and $\mathrm{pH}$ on trace metal speciation in seawater. Mar. Chem. 25: 163-181.

Caeiro, S., Costa, M. H., Ramos, T. B., 2005. Assessing Heavy Metal Contamination in Sado Estuary Sediment: An Index Analysis Approach. Ecol. Indi. 5: 151-169

Caldeira, K., Wickett, M.E. 2003. Oceanography: anthropogenic carbon and ocean pH. Nature. 425: 365

Capaccioni, B., Tassi, F., Vaselli, O., 2001. Organic and inorganic geochemistry of low temperature gas discharges at the Baia di Levante beach, Vulcano Island, Italy. J. Volcanol. Geoth. Res. 108: 173-185

Caramanna, G., Espa, S., Bouche, V. 2010. Study of the environmental effects of submarine $\mathrm{CO}_{2}$-rich emissions by means of Scientific diving techniques (Panarea Island-Italy). Int. J. of the Society for Underwater Tech. 29: 79-85

Caramanna, G., Voltattorni, N., Maroto-Valer, M.M., 2011. Is Panarea Island (Italy) a valid and cost-effective natural laboratory for the development of detection and monitoring techniques for submarine $\mathrm{CO}_{2}$ seepage? Greenhouse Gases: Sci. Technol. 1: 200-210 
Catsiki, V. A. and Panayotidis, P., 1993. Copper, chromium and nickel in tissues of the Mediterranean seagrasses Posidonia oceanica and Cymodocea nodosa from Greek coastal areas. Chemosphere. 26:963-978.

Connell, S.D., Doubleday, Z.A., Hamlyn, S.B., Foster, N.R., et al., 2017. How ocean acidification can benefit calcifiers. Cur. Bio.3:95-96.

Coles, R. G., McKenzie, L. J., Rasheed, M. A., Mellors, J. E., et al., 2007. Status and Trends of Seagrass Habitats in the Great Barrier Reef World Heritage Area. Report to the Marine and Tropical Sciences Research Facility. Reef and Rainforest Research Centre Limited, Cairns (122 pp.).

Cravo, A., Foster, P., Almeida, C., Company, R., et al., 2007. Metals in the shell of Bathymodiolus azoricus from a hydrothermal vent site on the Mid-Atlantic Ridge. Environ. Int. 33: 609- 615.

Dando, P. R., Stuben, D. \& Varnavas, S. P., 1999. Hydrothermalism in the Mediterranean Sea. Prog. Oceanogr. 44:333-367

D’Alessandro, W., Brusca, L. Kyriakopouios, K., Michas, G. et al., 2008. Methana, the westernmost active volcanic system of the South Aegean Arc (Greece): Insights from fluids geochemistry. Jour. Of Volcano. And Geoth. Res. 178: 818-828

De Orte, M. R., Sarmiento, A. M., Basallote, M. D., Rodríguez- Romero, A., et al., 2014. Effects on the mobility of metals from acidification caused by possible $\mathrm{CO}_{2}$ leakage from sub-seabed geological formations. Sci. Total Environ. 470: 356-363

Dickson, A.G., Sabine, C.L., Christian, J.R., (Eds), 2007.Guide to best practices for ocean $\mathrm{CO}_{2}$ measurements. PICES Special Publication, 3: 1-191

Di Leo, A., Annicchiarico, N., Cardellicchio, L., 2013. Trace metal distribution in Posidonia oceanica and sediments from Taranto Gulf (Ionian Sea, Southern Italy). Med. Mar. Sci. 14: 204-213

Dong, Y., Rosenbaum, R.K., Hauschild, M.Z., 2016. Assessment of metal toxicity in marine ecosystems; comparative toxicity potentials for nine cationic metals in coastal water. Env. Sci. and Tech. 50: 269-278.

Eggleton, J., Thomas, K.V., 2004. A review of factors affecting the release and bioavailability of contaminants during sediment disturbance events. Environ. Int. 30: 973980

Enochs, I.C., Manzello, D.P., Donham, E.M., Kolodziej, G., et al. 2015.Shift from coral to macroalgae dominance on a volcanically acidified reef. Nat. Climate Change. 5:1083-88.

EPA, 2007. Framework for Metal Risk Assessment. U.S Environmental Protection Agency. Office of the Science Advisor, Washington D.C

Fabricius, K.E., Death, G., Noonan, S., Uthicke, S., 2014. Ecological effects of ocean acidification and habitat complexity on reef-associated macroinvertebrate communities. Proc. R. Soc. B Biol. Sci. 281 (1775) 
Fan, W., Wang, W-X., Chen, J., Li, X., et al.,2002. Cu, Ni and Pb speciation in surface sediments from a contaminated bay of northern China. Mar. Pollut. Bull.44:816-32.

Fergusson, J.E., 1990. The heavy elements' chemistry, Environmental impacts and Health effects. Pergamon Press, Oxford, UK.

Fourqurean, J.W., Duarte, C.M., Kennedy, H., Marbà, N., et al., 2012. Seagrass ecosystems as a globally significant carbon stock. Nat. Geosci. 5: 505-509

Gabianelli, G., Gillot, P.Y., Lanzafame, G., Romagnoli, C. et al., 1990. Tectonic and volcanic evolution of Panarea (Aeolian Islands, Italy). Mar. Geo. 92: 313-326

Goffredo, S., Prada, F., Caroselli, E., Capaccioni, B., et al., 2017. Biomineralization control related to population density under ocean acidification. Nat. Climate. Change. 4:593-597.

Govers, L.L., Lamers, L.P.M., Bouma, T.J., Eygensteyn, J., 2014. Seagrasses as indicators for coastal trace metal pollution: a global meta-analysis serving as a benchmark, and a Caribbean case study. Environ. Pollut. 195, 210-217. http://dx.doi.org/10.1016/j. envpol.2014.08.028

Guilizzoni, P., 1991. The role of heavy metals and toxic materials in the physiological ecology of submersed macrophyte. Aqua. Bot. 41:87-109.

Hall-Spencer, J.M., Rodolfo-Metalpa, R., Martin, S., Ransome, E. et al., 2008. Volcanic carbon dioxide seeps show ecosystem effects of ocean acidification. Nature 454:96-99

IPCC. 2014. Fifth Assessment Report on Climate change: Impacts, Adaptation and Vulnerability

Inguaggiato, S., Mazot, A., Diliberto, I.S., Inguaggiato, C., Madonia, P., Rouwet, D. et al., 2012. Total $\mathrm{CO}_{2}$ output from Vulcano Island (Aeolian Islands, Italy). Geochem. Geophys. Geosyst. 13: Q02012

Ivanina, A.V., Sokolova, I.M., 2015. Interactive effects of metal pollution and ocean acidification on physiology of marine organisms. Cur. Zool. 64: 653-668.

Kadar, E., Costa, V., Segonzac, M., 2007. Trophic influences of metal accumulation in natural pollution laboratories at deep-sea hydrothermal seeps of the Mid- Atlantic Ridge. Sci. Tot. Environ. 373: 464-472.

Kabata-Pendias, A., Mukherjee, A.B., 2007. Trace Elements from Soil to Human. Springer, Berlin, Heidelberg.

Kadar, E., Fisher, A., Stolpe, B., Harrison, R.M. et al., 2012. Metallic nanoparticle enrichment at low temperature, shallow $\mathrm{CO}_{2}$ seeps in Southern Italy. Mar. Chem. 140: 24-32

Klumpp, D.W., Howard, R.K., Pollard, D.A., 1989. Trophodynamics and nutritional ecology of seagrass communities. Elsevier, Amsterdam, pp-394-437

Koch, M., Bowes, G., Ross, C., Zhang, X., 2013. Climate change and ocean acidification effects on seagrasses and marine macroalgae. Glob. Change Biol. 19:103-132. 
Kroeker, K. J., Kordas, R.L., Crim, R., Hendriks, I.E. et al., 2013. Impacts of ocean acidification on marine organisms: quantifying sensitivities and interaction with warming. Glob. Change Biol. 19:1884-1896

Lacoue-Labarthe, T., Martin, S., Oberhansli, F., Teyssie, J.L. et al., 2009. Effects of increased $\mathrm{pCO}_{2}$ and temperature on trace element $(\mathrm{Ag}, \mathrm{Cd}$ and $\mathrm{Zn}$ ) bioaccumulation in the eggs of the common cuttlefish, Sepia officinalis. Biogeosciences, 6: 2561-2573.

Lacoue-Labarthe, T., Martin, S., Oberhansli, F., Teyssie, J.L. et al., 2012. Temperature and $p \mathrm{CO}_{2}$ effect on the bioaccumulation of radionuclides and trace elements in the eggs of the common cuttlefish, Sepia officinalis. J. of Exp. Mar. Bio. and Eco. 413:45-49

Lafabrie, C., Pergent, G., Kantin, R., Pergent-Martini, C.et al., 2007. Trace metals assessment in water, sediment, mussel and seagrass species - Validation of the use of Posidonia oceanica as a metal bio monitor. Chemosphere 68: 2033-2039.

Lau, S., Mohamed, M., Tan Chi Yen, A., Suut, S., 1998. Accumulation of heavy metals in freshwater molluscs. Sci. Total Environ. 214:113-121.

Lauritano, C., Ruocco, M., Dattolo, E., Buia, M.C., et al., 2015. Response of key stressrelated genes of the seagrass Posidonia oceanica in the vicinity of submarine volcanic vents. Biogeo. Discus. 12: 4947-4971

Lemasson, A.J., Fletcher, S., Hall-Spencer, J.M., Knights, A.M., 2017. Linking the biological impacts of ocean acidification on oysters to changes in ecosystem services: A review. J. of Expt. Mar. Bio. and Ecol. 492:49-62

Llagostera, I., Pérez, M. \& Romero, J. 2011. Trace metal content in the seagrass Cymodocea nodosa: Differential accumulation in plant organs. Aqua. Bot. 95: 124-128

Lewis, M.A., Devereux, R., 2009. Non-nutrient anthropogenic chemicals in seagrass ecosystems: fate and effects. Environ. Toxicol. Chem. 28: 644- 661

Lewis, C. Ellis, R.P., Mangan, S., Campbell, A.L., 2014. Ocean acidification increases copper toxicity to the early life history stages of the Polychaete Arenicola marina in artificial seawater. Envir. Sci. \& Tech. 48:9745-9753

Lewis, C., Ellis, R.P., Vernon, E., Elliot, K., et al., 2016. Ocean acidification increases copper toxicity differentially in two key marine invertebrates with distinct acid-base responses. Nature. 6: 1-10.

Long, E. R., and D. D. MacDonald., 1998. Recommended uses of empirically derived, sediment quality guidelines for marine and estuarine ecosystems. Hum. and Ecol. Risk Assess. 4; 1019-1039.

MacDonald, D. D., Carr, R. S., Calder, F. D., Long, E. R, et al., 1996. Development and evaluation of sediment quality guidelines for Florida coastal waters. Ecotoxicology. 5:253278

MacDonald, D.D., Lindskoog, R.A., Smorong, D.E., Greening, H., et al., 2000. Development of an Ecosystem-based Framework for Assessing and Managing Sediment Quality Conditions in Tampa Bay, Florida. Tampa Bay Estuary Pro- gram, Florida, USA. 
Malea, P., Haritonidis, S., Kevrekidis, T., 1994. Seasonal and local variations of metal concentrations in the seagrass Posidonia oceanica (L.) Delile in the Antikyra Gulf, Greece. Sci. of the Total Env. 153: 225- 235.

Malea, P., Kevrekidis, T., 2013. Trace element (Al, As, B, Ba, Cr, Mo, Ni, Se, Sr, Tl, U and V) distribution and seasonality in compartments of the seagrass Cymodocea nodosa. Sci. Total Environ. 463: 611-623.

Malea, O. and S. Haritonidis., 1999. Cymodocea nodosa (Ucria) Aschers. as a Bioindicator of Metals in Thermaikos Gulf, Greece, during Monthly Samplings. Bot. Mar. 42: 419-430

Milazzo, M., Rodolfo-Metalpa, R., Chan, V.B.S., Fine, M. et al., 2014. Ocean acidification impairs vermetid reef recruitment. Scienti. Rep. 4 (4189).

Milazzo, M., Cattano, C., Alonzo, S.H., Foggo, A. et al., 2016. Ocean acidification affects fish spawning but not paternity at $\mathrm{CO}_{2}$ seeps. Royal Society. 283 (1835).

Millero, F.J., Woosley, R., DiTrolio, B., Waters, J., 2009. Effect of ocean acidification on the speciation of metals in seawater. Oceanography. 22:72-85.

Monia-Renzi, Teresa, R., C, G., Guido, P., Italianod, S. E et al., 2011. Temporal trends and matrix-dependent behaviors of trace elements closed to a geothermal hot-spot source (Aeolian Archipelago, Italy). Proced. Earth and Planetary Sci. 4:10 - 28

Olive, I., Silva, J., Lauritano, C., Costa, M.M., et al., 2017. Short term responses of seagrasses exposed to $\mathrm{CO}_{2}$ in volcanic vents. Scientific Rep.7:42278

Orth, R.J., Carruthers, T.J.B., Dennison, W.C., Duarte, C.M. et al., 2006. A Global Crisis for Seagrass Ecosystems. BioScience 56: 987-996.

Pascal, P.Y., Fleeger, J.W., Galvez, F., Carman, K.R., 2010. The toxicological interaction between ocean acidity and metals in coastal meiobenthic copepods. Mar. Pollut. Bull. 60: 2201-2208

Pierrot, D., Lewis, E. \& Wallace, D. W. 2006. MS Excel Program Developed for $\mathrm{CO}_{2}$ System Calculations Program developed for $\mathrm{CO}_{2}$ system calculations. ORNL/CDIAC-105a. (Carbon Dioxide Information Analysis Centre, Oak Ridge National Laboratory, US Department of Energy).

Prange, J, A, Dennison, W.C., 2000. Physiological responses of five seagrass species to trace metals. Mar. Pollut. Bull., 41: 327-336

Prokop, Z., Vangeheluwe, M.L., Van Sprang, P.A., Janssen, C.R., et al., 2003.Mobility and toxicity in sandy sediments deposited on land. Ecotox. Environ. Saf. 34: 65-73

Quinn, G. P. and Keough, M. J.: Experimental design and data analysis for biologists, Cambridge University Press, Cambridge, 2002.

Ralph, P.J., David, T., Kenneth, M., Stephanie, S. et al., 2006. Human impacts on seagrasses: eutrophication, sedimentation, and contamination. In: Larkum, A.W.D., Orth, R.J., Duarte, C.M. (Eds.), Seagrasses: Biology, Ecology and Conservation. Springer, Dordrecht, The Netherlands, pp. 567-593. 
Riba, I., Delvalls, T., Á.; Forja, J. M., Gómez-Parra, A., 2004. The influence of pH and salinity on the toxicity of heavy metals in sediment to the estuarine clam Ruditapes philippinarum. Environ. Toxicol. Chem. 23: 1100-1107

Richards, R., Chaloupka, M., Sano, M., Tomlinson, R., 2011. Modelling the effects of "coastal" acidification on copper speciation. Ecol. Model. 222: 3559-3567

Richir, J., Gobert, S., 2013. The effect of size, weight, body compartment, sex and reproductive status on the bioaccumulation of 19 trace elements in rope-grown Mytilus galloprovincialis. Ecol. Ind. 36: 33-47

Richir, J., Gobert, S., 2016. Trace elements in Marine Environment; Occurrence, Threats and Monitoring with Special Focus on the Coastal Mediterranean. Env. \&Anal. Toxicol. 6:1-19

Roberts, D. A., Birchenough, S.R., Lewis, C., Sanders, M.B. et al., 2013. Ocean acidification increases the toxicity of contaminated sediments. Glo. Change Bio. 19: 340-351

Ruocco, M., Musacchia, F., Olive, I., Costa, M.M., et al., 2017.Genomewide transcriptional reprogramming in the seagrass Cymodocea nodosa under experimental ocean acidification. Mol. Ecol. 16: 4241-4259

Russell, B.D., Connell, S.D., Uthicke, S., Muehllehner, N. et al., 2013. Future seagrass beds: can increased productivity lead to increased carbon storage? Mar. Pollut. Bull. 73:463-469

Sanchiz, C., Garcia-Carrascosa, A.M., Pastor, A., 2001. Relationships between sediment physico-chemical characteristics and heavy metal bioaccumulation in Mediterranean softbottom macrophyte. Aquat. Bot. 69: 63-73

Sedwick PN, Stuben D., 1996. Chemistry of shallow submarine warm springs in an arcvolcanic setting: Volcano Island, Aeolian Archipelago, Italy. Mar. Chem. 53: 147-161.

Shi, W., Zhao, X., Han, Y., Che, Z., et al., 2016. Ocean acidification increases cadmium accumulation in marine bivalves: a potential threat to seafood safety. Sci. Rep. 6:20197

Simpson, S.L., Rochford, L., Birch, G.F., 2002. Geochemical influences on metal partitioning in contaminated estuarine sediments. Mar. Freshwater. Res. 53: 9-17

Simpson, S.L., Batley, G.E., 2003. Disturbances to metal partitioning during toxicity testing iron(II)-rich estuarine pore waters and whole- sediments. Environ. Toxicol. Chem. 22: 424432

Simpson, S.L., Angel, B.M., Jolley, D.F., 2004. Metal equilibration in laboratorycontaminated (spiked) sediments used for the development of whole-sediment toxicity tests. Chemosphere 54: 597-609

Sternbeck J, Östlund P., 2001. Metals in sediments from the Stockholm region: Geographical pollution patterns and time trends. Water Air Soil Pollut. Focus. 1:151-165

Stoffers, P., Hannington, M., Wright, I., Herzig, P. et al., 1999. Elemental mercury at submarine hydrothermal seeps in the Bay of Plenty, Taupo volcanic zone, New Zealand. Geol. Society of America. 10: 931-934 
Stumm, W., and Morgan, J.J., 1995. Aquatic chemistry: chemical equilibria and rate in natural waters, 3 rd ed.

Sunday, J.M., Fabricius, K.E., Kroeker, K.J., Anderson, K.M. et al., 2016. Ocean acidification can mediate biodiversity shifts by changing biogenic habitat. Nat. Clim. Change. 7: $81-85$

Szefer, P., Ali, A.A., Ba-Haroon, A.A., Rajeh, A.A., et al., 1999. Distribution and relationships of selected trace metals in molluscs and associated sediments from the Gulf of Aden, Yemen. Environ. Pollut. 106: 299-314

Tanhua, T., Hainbucher, D., Schroeder, K., Cardin, V., et al., 2013. The Mediterranean Sea system: A review and an introduction to the special issue. Ocean Sci.5:789-803.

Tchounwou, P.B., Yedjou, C.G., Patlolla, A.K., Sutton, D.J., 2014. Heavy metals toxicity and the Environment. Mol., Clinical and Env. Toxicol. 101:133-164

Tedesco, D., 1996. Chemical and isotopic investigation of fumarolic gases from Ischia Island (Southern Italy): evidence of magmatic and crustal contribution. J. Vulcanol. Geother. Res. 74:233-242

Thom, R. M., 2001. Carbon Sinks in Nearshore Marine Vegetated Ecosystems. Pacific Northwest Laboratory, Marine Science Laboratory.

Underwood, A. J.1997. Experiments in Ecology: Their Logical Design and Interpretation Using Analysis of Variance, Cambridge University Press, Cambridge.

United Nations (2015), Transforming our World; The 2030 Agenda of Sustainable Development, United Nations Secretariat, New York, United States.

Voltattorni, N., Sciarra, A., Caramanna. G., Cinti. D. et al., 2009. Gas geochemistry of natural analogues for the studies of geological $\mathrm{CO}_{2}$ sequestration. Applied Geochem. 24:1339-1346

Vizzini, S, Tomasello, A., Maida, G. Di, Pirrotta, M. et al., 2010. Effect of explosive shallow hydrothermal seeps on $13 \mathrm{C}$ and growth performance in the seagrass Posidonia oceanica. J. of Ecol. 98:1284-1291

Vizzini, S, Di Leonardo, R., Costa, V., Tramati, C.D. et al., 2013. Trace element bias in the use of $\mathrm{CO}_{2}$ seeps as analogues for low $\mathrm{pH}$ environments: Implications for contamination level in acidified oceans. Estuarine, coast. and Shelf Sci. 134:19-30

Weis, J. S., Weis, P., 2004. Metal uptake, transport and release by wetland plants: implications for phytoremediation and restoration. Environ. Int.30:685-700.

Yang, J., Ye, Z., 2009. Metal accumulation and tolerance in wetland plants. Front. Biol. China 4 (3), 282-288. doi.org/10.1007/s11515-009-0024-7

Zeng, X., Chen, X., 2015. The positive relation between ocean acidification and pollution. Mar. Poll. Bull. 91:14-21.

Zoumis, T., Schmidt, A., Grigorova, L., Calmano, W., 2001. Contaminants in sediments: remobilisation and demobilisation. Sci. Total Environ. 266: 195-202 
bioRxiv preprint doi: https://doi.org/10.1101/433987; this version posted October 3, 2018. The copyright holder for this preprint (which was not certified by peer review) is the author/funder, who has granted bioRxiv a license to display the preprint in perpetuity. It is made available under aCC-BY-NC-ND 4.0 International license. 